\title{
Dynamics of river plumes in the South Brazilian Bight and South Brazil
}

\author{
Martinho Marta-Almeida ${ }^{1,2}$ (D) . Anna Dalbosco ${ }^{3}$. David Franco ${ }^{3}$. Manuel Ruiz-Villarreal ${ }^{2}$
}

Received: 25 December 2018 / Accepted: 6 July 2020 / Published online: 11 November 2020

(C) The Author(s) 2020

\begin{abstract}
The plumes from the rivers of the South Brazilian Bight (SBB) and South Brazil (SB) were studied using a realistic model configuration. River plume variability on continental shelves is driven by the input of river runoff into the shelf, by wind variability, and also by ambient currents and its seasonal variability, especially the Brazil Current, which are realistically modelled in this study. It is presented a simulation of 4 years using a nested configuration, which allows resolving the region around Florianópolis with very high resolution $(\sim 150 \mathrm{~m})$. The dispersion of river plumes was assessed not only with the hydrodynamical model results but also by using passive tracers whose dynamics was analyzed seasonally. Several dyes were released together with the river discharges. This approach allowed calculating the depths of the riverine freshwater, and the resulting regions affected by the plumes. Northward intrusions of waters from the southern region, under the potential influence of the distant La Plata river plume, were evaluated with a Lagrangian approach. The local river plumes are confined to the inner shelf, except south of $30^{\circ} \mathrm{S}$ where discharges from Lagoa dos Patos disperse over the shelf in the spring and summer. The Brazil Current flowing southward over the slope prevents the river plumes from interaction with oceanic mesoscale dynamics. The river plumes are, thus, mainly controlled by the wind forcing. The plumes from SBB are able to disperse until SB following the southward wind regime typical of the summer. And both the SB and La Plata river plumes are also able to reach SBB, forced by the northward wind typical of the winter season, until the latitude of $25.5^{\circ} \mathrm{S}$. A low salinity belt (below 35) is present along the coastal region of SB and SBB year-round, supported by contributions from both the large and small rivers. The interaction between the different plumes influences the dispersion patterns, shielding the Florianpolis coastal region from plumes of distant rivers, and dispersing the plume of SBB rivers away from Santa Catarina Island as it disperses southward during the summer months.
\end{abstract}

Keywords South Brazilian Bight · South Brazil · Florianópolis · River plumes dispersion · River plumes interaction · 2-way model nesting

\section{Introduction}

Florianópolis is located in the Brazillian coastal region around $27^{\circ} \mathrm{S}$, in the state of Santa Catarina. It consists of a main island, also called Santa Catarina; a continental

Responsible Editor: Ricardo de Camargo

This article is part of the Topical Collection on the 11th International Workshop on Modeling the Ocean (IWMO), Wuxi, China, 17-20 June 2019

Martinho Marta-Almeida mma@uvigo.es

Extended author information available on the last page of the article. part; and several small islands (Fig. 1). The region has an important metropolitan area and several main ports, including the Port of Itajaí, the second largest of the country in container handling. There is a growing concern over urban discharges and industrial activity, including oil exploration, affecting the beaches and coastal waters. As a consequence, there are impacts on the quality of life, in coastal ecosystems, and in environmentally protected regions, like the Arvoredo Marine Biological Reserve, located very close to urban areas (Fig. 1c). Santa Catarina Island is approximately $54 \mathrm{~km}$ long and $18 \mathrm{~km}$ wide, and the narrowest channel separating it from the coast is about 400 $\mathrm{m}$ wide. To the north, between the mainland and the island, there is the North Bay ( $\sim 10 \mathrm{~km}$ wide) and to the south, the South Bay ( $\sim 6 \mathrm{~km}$ wide) ending in another narrow channel $1 \mathrm{~km}$ wide. 


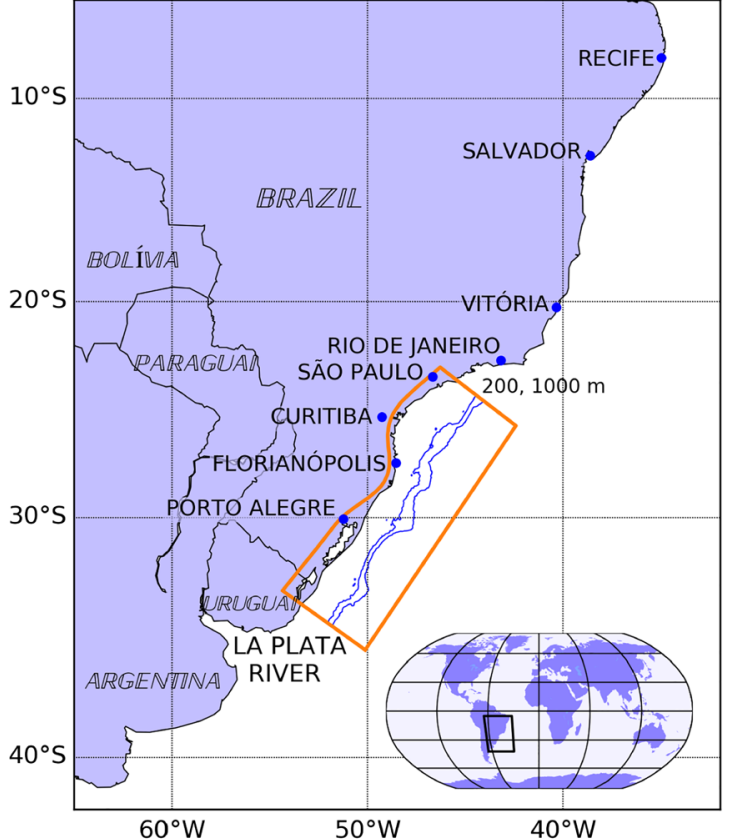

(a) Model domain D1

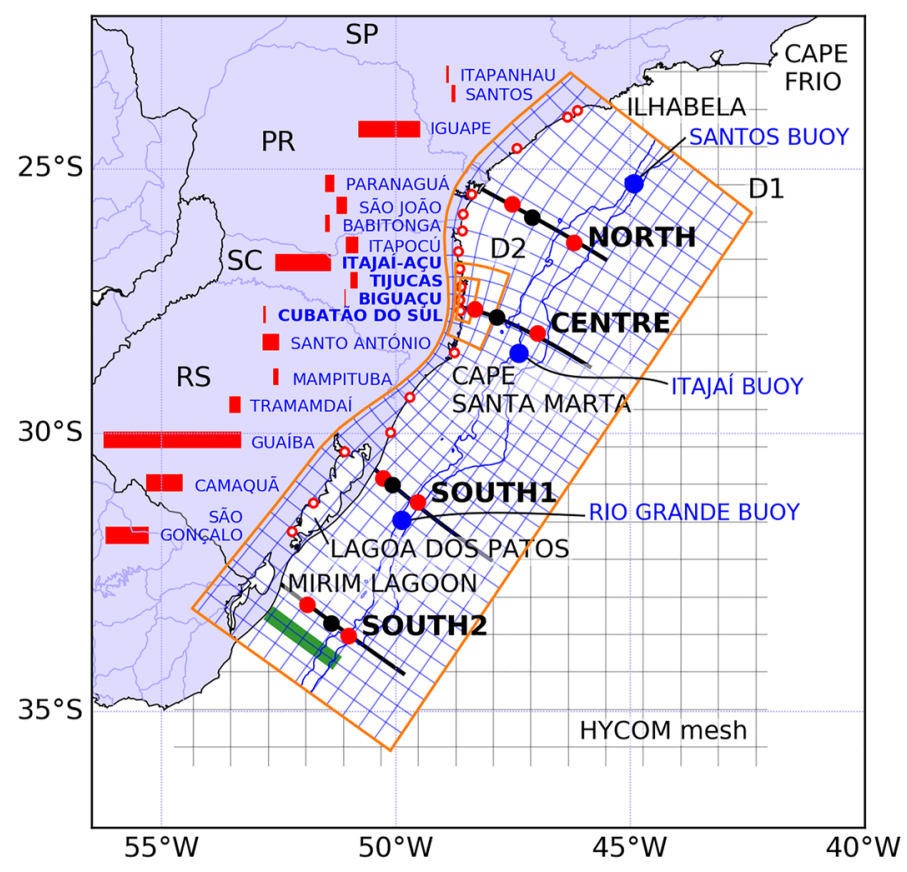

(b) Model domains and rivers

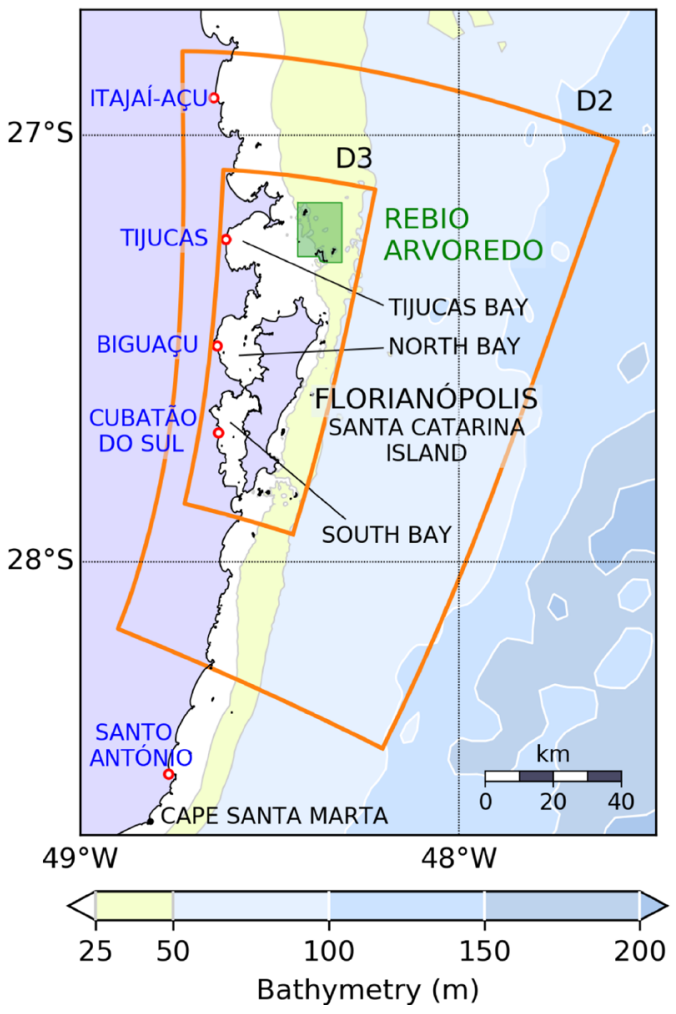

(c) Model domains D2 and D3

Fig. 1 Regions of study. a Geographical location of the model domain D1. b D1 and HYCOM meshes every 10 grid lines and location of the rivers, where the relative mean discharge is indicated by the red horizontal bars (discharge values are provided in Fig. 2); the highlighted river names indicate the rivers in the region of Florianópolis; the green rectangle near the southern domain boundary is the region of Lagrangian floats release; the four transects (labelled north, centre, south1, and south2) show locations were vertical profiles of several variables are analyzed; the sets of three dots on each transect indicate sites where wind (black dots) and currents (red dots) time series were extracted; the three blue dots indicate buoys used for model validation. c Zoom around Florianópolis showing the domains D2 and D3 
In order to understand the oceanic features of the region surrounding Florianópolis, several oceanic observational and modelling projects have been conducted (e.g., Noernberg and Alberti 2014; de Souza and Schettini 2014; Bordin et al. 2019). It has been, however, difficult to simulate realistically this very small-scale region because of the influence of large-scale forcings. For instance, the need to include in the simulations accurate tidal circulation and river forcing away from the region of study may require a large domain, compromising the high resolution needed. Rivers and regional coastal features like upwelling, away from the site but important for the region, may not be present in the parent global- or basin-scale model/dataset used to force the local regional model. In particular, the riverine freshwater has an important role in coastal systems, generating density gradients and currents and thus is important for dispersal of pollutants in industrialized regions or marine routes (e.g., Kourafalou and Androulidakis 2013; Marta-Almeida et al. 2013b; Magris et al. 2019), for marine reproduction and growth (e.g., Lohrenz et al. 1999) and for the whole ecosystem in general (e.g., Hickey et al. 2010; Waterhouse et al. 2012). Even relatively small amounts of discharge may be crucial in regions dozens or hundreds of $\mathrm{km}$ away from the discharge locations.

The region of Florianópolis lies in the south of the South Brazilian Bight (SBB), extending from Cape Frio $\left(23^{\circ} \mathrm{S}\right)$ to Cape Santa Marta $\left(28.6^{\circ} \mathrm{S}\right)$, with an along coast extension of about 1000 km (Fig. 1). South of Cape Santa Marta, down to the Brazil-Uruguay boundary, is the South Brazil region (SB), with an extension of $720 \mathrm{~km}$. The coastal region of the SBB and SB has been studied over the past with models and observations, more intensively on the southern part around Lagoa dos Patos (e.g., Zavialov et al. 2002; Soares and Möller 2001; Soares et al. 2007a, b; Palma et al. 2008; Matano et al. 2010). In general, the studies at coastal scale are focused on a particular region, and large-scale studies are typically focused on certain periods (believed to be characteristics of the seasonal variability), or, in case of modelling studies, they frequently lack the realistic capabilities that are nowadays available to the modelling community. Being located in a region with strong mesoscale features and the presence/influence of the La Plata river, the role of several freshwater sources along the coast has been typically disregarded, or at least not included in large-scale studies, eventually with the exception of the river discharges into Lagoa dos Patos (e.g., Palma et al. 2004; Soares et al. 2007a, b; Palma et al. 2008; Matano et al. 2010; Mendonça et al. 2017). For instance, south of Ilhabela archipelago, the SBB has an average riverine freshwater input of about $1600 \mathrm{~m}^{3} \mathrm{~s}^{-1}$, including the rivers from Itapanhau to Santo António (Figs. 1b and 2). This value is comparable to the discharge into Lagoa dos Patos, the main fresh water source of SB (excluding the low salinity waters entering through the south originated in the La Plata river), with an average discharge of $1844 \mathrm{~m}^{3} \mathrm{~s}^{-1}$ (includes the rivers Guaíba, Camaquã, and the São Gonçalo Channel, connecting Mirim Lagoon and Lagoa dos Patos). The importance for shelf dynamics of relatively small, but closely spaced rivers, has been reported in the literature (e.g., Peliz et al. 2002; Otero et al. 2008; Saldías et al. 2016; Osadchiev and Korshenko 2017). And while studies of large river plumes sometimes consider them independent from small sources, their fate and dispersion may be strongly influenced by plume-toplume interactions (Warrick and Farnsworth 2017).

In terms of circulation and water masses, the region is dominated by two mesoscale features: the warm and salty Brazil Current (BC) transporting tropical water (TW) over the slope (Stramma et al. 1990) and South Atlantic Central Water (SACW) under the TW (SACW off BC extends over the platform until the coast) and the Malvinas Current (MC) which meets the $\mathrm{BC}$ by the latitude of La Plata river, off Argentina, at the Brazil-Malvinas Confluence (BMC, Piola and Matano 2001). The shelf of Uruguay and the region around the Brazil southern boundary is characterized by the presence of fresh waters from river La Plata which extends northward in late fall, and retracts during the spring/summer months, having the wind as forcing mechanism (Palma et al. 2004; Piola 2005; Soares et al. 2007b; Burrage et al. 2008; Möller et al. 2008; Pezzi et al. 2016). The freshwater from Lagoa dos Patos and intrusions of sub-Antarctic Shelf waters exhibit the same seasonal pattern (Palma et al. 2008). The La Plata plume reaches $38^{\circ} \mathrm{S}$ and $28^{\circ} \mathrm{S}$ (very close to Florianópolis), representing excursions of about $1200 \mathrm{~km}$ (Palma et al. 2008). Some studies believe the possibility of the presence of the La Plata plume further north, reaching the southern regions of the SBB (e.g., Piola et al. 2000). This winter time northward-flowing coastal current, opposed to the $\mathrm{BC}$ and carrying cold and fresh waters, has been called Brazilian Coastal Current (BCC) (Zavialov et al. 2002; de Souza and Robinson 2004; Palma et al. 2008). While under the influence of La Plata discharge and wind driven away from La Plata river mouth, it is also argued that the BMC may play a role in the development of the BCC, namely due to the spreading of cross-shelf pressure gradients created by the MC (Palma et al. 2008). At subsurface, the Uruguay$\mathrm{SB}$ region is dominated by the Subantarctic Shelf Water from the south and the Subtropical Shelf Water, from the north. These water masses are separated by the Subtropical Shelf Front, extending meridionally south of Lagoa dos Patos (Piola et al. 2000, 2008; Mendonça et al. 2017). The Subtropical Shelf Water is originated by dilution of SACW with freshwater discharges by SB rivers and by the La Plata river.

In general, the major forcings of the SBB and SB are wind, tides, riverine freshwater and western boundary currents. Contrarily to the Patagonia Shelf (south of $40^{\circ} \mathrm{S}$ ), 


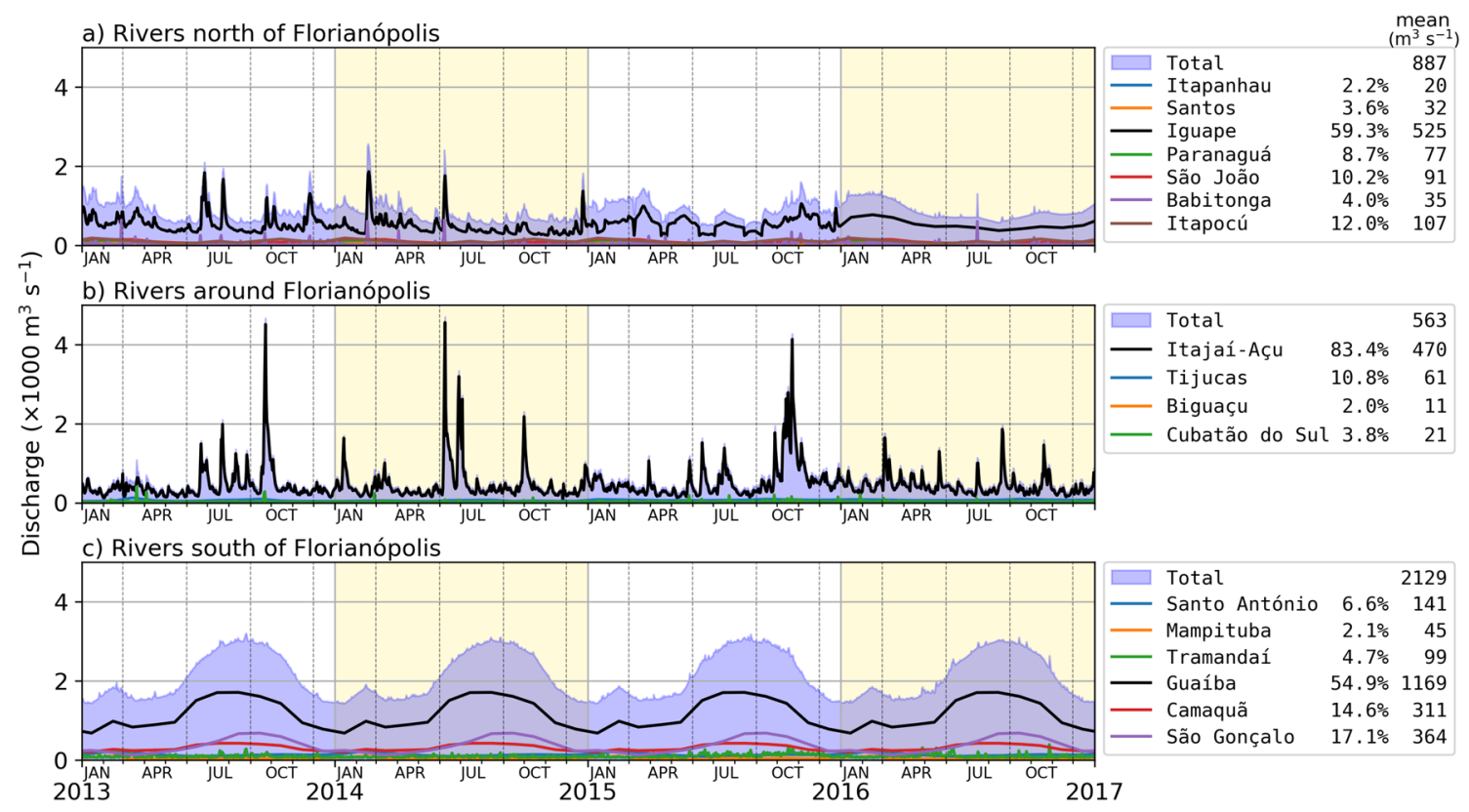

Fig. 2 Discharges of the rivers north of Florianópolis (a), in the Florianópolis region (b, inside domain D2) and south of Florianópolis (c). The legends show the river names and the percentage contribution of each river to the total discharge in each of the regions, as well as the mean discharges $\left(\mathrm{m}^{3} \mathrm{~s}^{-1}\right)$. The rivers are indicated from North to South and the largest river in each subregion is shown in black tides north of the La Plata river are week and the shelf circulation is mainly driven by river discharges and wind. The region is characterized by northeasterly winds throughout the year (Satyamurty et al. 1998), a pattern that is modified by the cold frontal systems, more frequent during austral winter (Campos et al. 1995; Palma 2004). The SBB is primarily driven by prevailing upwelling favorable southward alongshore winds and offshore by the BC (Matano et al. 2010), which shows no significant seasonal variability. Increased turbulence has been identified in previous studies (e.g., Oliveira et al. 2009) at the SBB and should be mainly associated with the abrupt change in coastline geometry south of Cape Frio. SB is mainly influenced by southward, seasonally reversing winds, by the discharges of La Plata river and Lagoa dos Patos, and offshore by the $\mathrm{BC}$ and the BMC.

The objective of this work is to study the seasonal dynamics of river plumes in the SBB and SB and the possibility of the plume dispersion to affect the region around Florianópolis. The modelling configuration presented addresses the difficulties of simulating both the large and the very small scales, taking into account the realistic mesoscale and other important forcings. The modelling approach uses stereoscopic 2-way online nesting, a relatively recent development in coastal modelling and used for the first time in the Brazillian region. This study tries to cope with the several limitations of common modelling practices in the region and gives attention to the many small riverine sources. The possibility of intrusions of the La Plata river waters in the SBB is also assessed. Model validation is provided against observations of temperature, salinity, currents, and sea level anomaly (in terms of geostrophic currents).

\section{Methods}

This modelling study used the primitive equations, freesurface, terrain-following Regional Ocean Modeling System (Haidvogel et al. 2008). Three online nested domains (2-way) were used (Fig. 1) with a nesting ratio of 5 . This means the resolution increases 25 times between the larger scale domain and the third, local very high-resolution domain. The parent domain, D1, extends from Ilhabela to the Brazil-Uruguay boundary, covering almost the entire SBB and the SB regions. The domain averaged horizontal resolution is $4385 \mathrm{~m}$ and around $4000 \mathrm{~m}$ in the Florianópolis region. The intermediate domain, D2, extends north (including river Itajaí-Açu) and south of Florianópolis and offshore until the $100 \mathrm{~m}$ isobath. The horizontal resolution is about $700 \mathrm{~m}$. The smallest domain, D3, covers the Santa Catarina island and adjacent waters with a resolution of about $150 \mathrm{~m}$. The vertical axis was discretized with $30 \mathrm{~s}$-levels. The configuration used fourth-order horizontal advection for momentum and third-order upwind advection for tracers. Explicit horizontal diffusion for momentum was set to $5 \mathrm{~m}^{2} \mathrm{~s}^{-1}$ in the coarse grid. The model ran 4 years, 20132016, with realistic atmospheric, tidal, riverine, and lateral forcings. 
Other realistic coastal modelling implementations using ROMS, although without nesting, have been done in several Brazilian regions in recent years at diverse time and space scales. These have been used to study subjects like ocean-continental shelf interactions (Amorim et al. 2013), upwelling processes (Aguiar et al. 2014, 2018), estuarine dynamics and exchange (Marta-Almeida et al. 2017, 2019; Aguiar et al. 2019), pollution dispersion (Marta-Almeida et al. 2016; Magris et al. 2019), and operational oceanography (Marta-Almeida et al. 2011a, b, 2013b). These modelling studies were implemented using one domain offline nested into large-scale or global models, which while a technique known to improve model skill (Marta-Almeida et al. 2013a), it may be difficult to simulate both the mesoscale and the very small-scale coastal/estuarine features without using online nesting. A very different approach was recently implemented in the Brazillian Northeast region, in which Marta-Almeida et al. (2019), using a multicorner domain, were able to span a wide range of spatial scales. Such technique, however, depends greatly on the geometry of the coastline and is not suitable for the current study region. Also recently, a coupled ocean-atmosphere configuration of ROMS was used for SB, Uruguay, and Argentina regions to study water masses and currents (Mendonça et al. 2017). The study used realistic atmospheric forcing (the same as here, described in the next paragraph), while having a climatological approach for the oceanic counterpart.

The surface forcing was obtained from the Climate Forecast System Reanalysis (CFSR, Saha et al. 2010), enabling the model to exchange momentum, heat, and fresh water with the atmosphere. The data is available every $6 \mathrm{~h}$ with a resolution of $0.3^{\circ}$. CFSR is considered more accurate than the previous reanalysis from NCEP (National Centers for Environmental Prediction), in particular in the Southern Hemisphere. This dataset has been successfully used in previous Brazilian coastal modelling studies (e.g., Aguiar et al. 2018; Magris et al. 2019; Marta-Almeida et al. 2019).

Tidal forcing was added to the parent domain D1 (Fig. 1b), consisting in tidal amplitudes and phases of tidal elevation and ellipses of the barotropic tidal currents. The tidal dataset used was TPXO (Egbert and Erofeeva 2002) which provided data for the main semi-diurnal $\left(\mathrm{M}_{2}, \mathrm{~S}_{2}, \mathrm{~N}_{2}\right.$, $\left.\mathrm{K}_{2}\right)$ and diurnal $\left(\mathrm{K}_{1}, \mathrm{O}_{1}, \mathrm{P}_{1}\right.$, and $\left.\mathrm{Q}_{1}\right)$ constituents.

As initial and lateral boundary conditions, D1 used state variables, free-surface and currents from the global model HYCOM-NCODA (Hybrid Coordinate Data Assimilation-Navy Coupled Ocean Data Assimilation, Wallcraft et al. 2009). This realistic dataset has a horizontal resolution of $1 / 12^{\circ}$ and is available with daily periodicity. Around the border of the domain it was applied a nudging relaxation towards the HYCOM solution (Marchesiello et al. 2001).
The main rivers inside the study region were used in the simulations, a total of 17 . Their locations and relative discharges are shown in Fig. 1b. The discharge time series, given in Fig. 2, are divided in rivers north of Florianópolis, rivers around Florianópolis (inside the intermediate domain D2), and rivers south of Florianópolis. These three regions represent $25 \%, 16 \%$, and $59 \%$ of the riverine discharges into de modelling domains, respectively. Daily discharges are available through measurements for part of the rivers, while others were introduced in the model as monthly climatologies. In the northern region, climatological values were used for some rivers, but for the main one, Iguape (about $60 \%$ of the discharge in this subregion), as well as for Babitonga, daily data were used. Iguape was used as climatological in 2016, though, due to the lack of observations available beyond 2015. In the central region, around Florianópolis, all the rivers have daily values except Biguaçu, which is a very small river, with an average discharge of $11 \mathrm{~m}^{3} \mathrm{~s}^{-1}$. In the southern region only Tramandaí has daily observations available, while the large rivers debouching in Lagoa dos Patos have climatological values, including the largest river used in this study, the Guaíba, with an average discharge higher than $1100 \mathrm{~m}^{3} \mathrm{~s}^{-1}$, close to $1 / 3$ of the total discharge in the simulations.

The seasonal variability of the river plume dispersion was evaluated with the help of passive tracers of unitary concentration (dyes). Four dyes were released: one for the rivers in the northern region (Fig. 2a), two for the central region (Fig. 2b), and one for the southern region (Fig. 2c). Due to the large discharge of river Itajaí-Açu in the central region, this river was studied alone with one dye, and another dye was assigned to the other three rivers of this subregion. While there are in the region rivers larger than Itajaí-Açu (rivers Guíba in the southern region and Iguape in the northern region), they represent about half of the discharge in their subregions, while Itajaí-Açu represents more than $80 \%$ of the discharge around Florianópolis. For this reason, it was studied with one dye while larger rivers, with a less relative contribution in their subregion, were studied together with the surrounding smaller sources. The dye concentration was then vertically integrated resulting in plume depths which indicate the regions of freshwater influence.

Releasing dyes into the rivers to study the riverine freshwater has been applied in many coastal modelling studies (e.g., Zhang et al. 2012; Marta-Almeida et al. 2016; Rayson et al. 2016; Magris et al. 2019). However, the linear relationship between river discharge and dye concentration is not always observed since there are sources (other than the rivers) and sinks of salinity in the ocean. In particular, for very low dye concentration, the water parcel may no longer have freshwater properties. Moreover, the salinity in the vicinity of one river also changes due to the presence of 
the plumes of other rivers, possibly simulated with different dyes. Finally, numerical over and undershoots of salinity may occur in the vicinity of the plume front, but can be controlled with implicit or explicit horizontal diffusion (Hetland 2005).

It becomes thus necessary to identify a minimum reference dye concentration below which it may no longer be considered that the dye represents riverine freshwater. For that, linear regression between the daily model output of shelf salinity and the sum of all dyes was used. The distribution of the dye values around the regression salinity for dye zero was then obtained (using a salinity range of 0.05 ) and the half maximum of dye variability was considered the reference value. This was done using the monthly averaged output from D1 (excluding the first year of the simulation), dividing the region every 10 grid cells along the coast. A schematic representation of the calculation of the reference dye is shown in Fig. 3a. The result is shown in Fig. 3b. From these time and space values, the percentile $75 \%$ was calculated resulting in a reference dye of 0.005 . A single value was adopted in order to obtain consistent results for the several subregions and periods analyzed. The percentile $75 \%$ was chosen as the value above which the main freshwater areas did not change appreciably.

The core of this study is seasonal, based on monthly means of freshwater depths. The first year of the simulation was not considered in the seasonal analysis since there are no dyes at the model initialization and because of the model spinup. While the numeric adjustment of the dynamics may be fast, the filling of the shelf with the riverine dyes may take several months. To help in the analysis, the monthly means of model surface salinity, temperature, currents, and wind were also calculated for the same period. In addition, four transects of salinity, temperature, currents, and dye concentration were analyzed, also in terms of monthly means, together with the wind and surface currents time series on the shelf over the transects. In order to have a broader picture of the interannual variability, the time series analysis was done for the entire simulation period, i.e., also including 2013.

The possible presence of La Plata river waters near Florianópolis, or even its migration to higher latitudes inside the SBB, was evaluated using a Lagrangian approach. Since La Plata is not inside the model domain (D1), the Eulerian approach cannot be used. Thus, a set of 66 particles was released near the model southern boundary every day and followed hourly during the whole simulation. The release location is indicated in Fig. 1a. The latitudinal variability was then analyzed, consisting of 96,426 trajectories (66 releases per day, for the four years of the simulation).

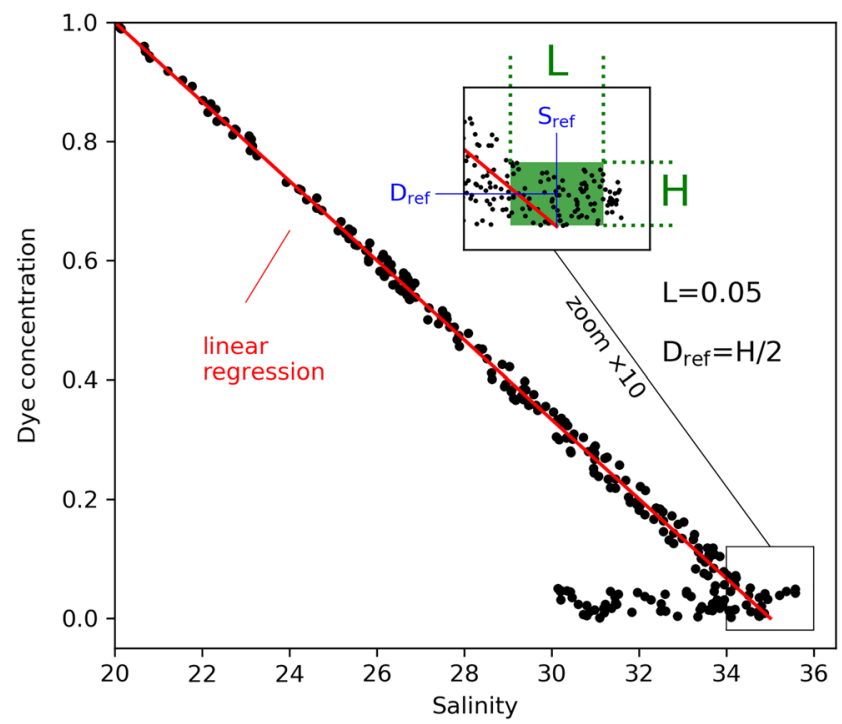

(a) Calculation of the reference dye

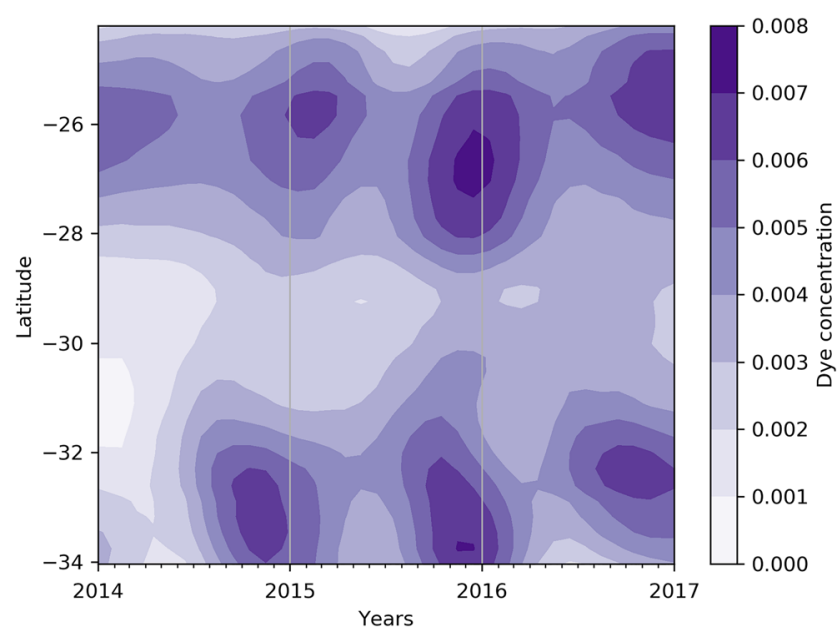

(b) Reference dye

Fig. 3 Schematic representation of the calculation of the reference dye $\left(D_{\text {ref }}\right)$ (a) and reference dye obtained, indicating the lower limit of riverine waters (dyes are released with unitary value) (b)

\section{Model validation}

River plume variability on continental shelves is in general driven by the input of river runoff, by wind variability, and also by ambient currents (Fong and Geyer 2002; Hickey et al. 2005; Choi and Wilkin 2007; Otero et al. 2008). The aim of this model validation section is not to validate the quick response of river plume to wind variations, since proper data sets are scarce, but to show the model reproduces realistically ambient circulation and its variability. Thus, sea surface salinity and temperature, and geostrophic currents, are used to show the BC that 
transports warmer and saltier waters southwards over the slope is modelled realistically. Adequate modelling of this slope current relies partly on the skill of the model in representing adjacent ocean waters, and this skill is shown by the comparison to a dataset of temperature and salinity profiles. Nevertheless, while there are no observations over the shelf, other than those provided by global datasets, there are three buoys at the shelf break inside the study domain. These buoys, operated by the Brazilian Navy, measure hourly sea surface temperature (SST) and currents in the upper ocean layer.

Although seasonal analysis of the results disregards the first year of simulation, the entire simulation period was used in the model validation.

The model sea surface salinity was compared with AQUARIUS satellite salinity (https://podaac.jpl.nasa.gov/ aquarius). AQUARIUS is available until the end of May 2015 as L4, with a spatial resolution of $0.5^{\circ}$ and one global snapshot per week. Model data was averaged for the time and space scales of AQUARIUS. The resulting spatial bias and root mean square error (RMSE) are shown in Fig. 4a, b. In order to evaluate the robustness of the model, the sea surface salinity of HYCOM (used as lateral forcing of the ROMS domain D1) was also compared with AQUARIUS (Fig. 4c). In addition, time series of RMSE were calculated for the ROMS output and for HYCOM. The result is shown in Fig. 4d. Model bias is in general between -0.5 and 0.5 , except in the coastal region of the SBB and in a large portion of the domain in front of Lagoa dos Patos. In the SBB coast, the model has lower salinity, while in the south, the model salinity is higher than AQUARIUS. This may be associated with the AQUARIUS lower capabilities near the coast and in regions influenced by large rivers, as is the case of SB (Kao et al. 2018). The model spatial RMSE is lower than 0.5 also in most of the domain, except in those areas with higher bias, where RMSE can reach values of 1.5. The HYCOM results show a very similar comparison, except in the inner shelf of the SBB, probably because HYCOM does not use realistic rivers in that region. The comparable ROMS and HYCOM errors give confidence in the model salinity in the southern region, where errors are higher. Ignoring regions with errors higher than 0.5 , the RMSE time series (Fig. 4d) shows errors in general lower than 0.15 and no predominance of ROMS or HYCOM in terms of better performance. In the first 3 months of the simulation period, the higher errors are not due to the model adjustment of the initial conditions, since they are also observed for HYCOM. They may be the result of some temporary deficiency in the HYCOM solution or in the satellite observations.

A similar comparison was done for SST (Fig. 5), using the Multi-scale Ultra-high Resolution Sea Surface Temperature Analysis (MUR_SST, https://mur.jpl.nasa.gov). This
L4 product combines satellite measurements with surface observations, providing daily SST with a spatial resolution of $0.01^{\circ}$. In most of the region, the model bias is between $-0.25{ }^{\circ} \mathrm{C}$ and $0.25{ }^{\circ} \mathrm{C}$, in particular in the region around the slope, where the warm BC flows. Bias higher than $1{ }^{\circ} \mathrm{C}$ is found in the inner shelf along the whole domain. This may be due to the lack of surface measured data in the coastal region of Brazil to correct the satellite values. The spatial RMSE (Fig. 5b, c) also shows errors higher than $1{ }^{\circ} \mathrm{C}$ in the coastal region as well as in at a portion of the shelf break and ocean at the south of the domain, where the actual eddy activity of the $\mathrm{BC}$ cannot be captured without data assimilation. In most of the regions around the slope, however, the errors are lower than $0.75{ }^{\circ} \mathrm{C}$. Regarding the HYCOM dataset, the higher errors are located at the same locations but in a much smaller extension. Comparing with ROMS, the HYCOM regions with errors higher than $1{ }^{\circ} \mathrm{C}$ are very small. HYCOM is an assimilated global model and it uses the same sources of SST as MUR_SST, so that this outcome is not surprising. The RMSE time series (Fig. 5d) confirms this result, with the ROMS errors higher most of the time. The difference is however small, being the mean errors of ROMS and HYCOM $0.62{ }^{\circ} \mathrm{C}$ and $0.58{ }^{\circ} \mathrm{C}$, respectively. While satellite uncertainties near the coast may justify, to some extent, the differences found, the wind resolution and the spatial variability of the water type (Jerlov 1976) may also be important for the accuracy of the surface thermal fluxes. The high RMSE found in the south of the domain, away from the coast, is less worrisome because in that region the bias is low.

In order to validate also the thermohaline structure, the profiles of temperature and salinity from the Coriolis Ocean Dataset for Reanalysis (CORA, Cabanes et al. (2013)) were compared with model results. The version 5.2 was used, having monthly composites with horizontal resolutions of $0.5^{\circ}$. The data is available between the surface and $2000 \mathrm{~m}$ depth. The model monthly means were horizontally and vertically interpolated to the CORA 3D coordinates and the comparison is shown in Fig. 6a, b. At the latitudes of the SBB and SB, the main water masses are TW at the upper layers around the slope; SACW between 100 and $500 \mathrm{~m}$ and; Antarctic Intermediate Water (AIW) at deeper layers (e.g., de Macedo-Soares et al. 2014). For temperature, above $100 \mathrm{~m}$, the differences between the mean profiles are about $0.3{ }^{\circ} \mathrm{C}$. The differences between the standard deviations of the spatial mean are lower than $0.5^{\circ} \mathrm{C}$. Below $100 \mathrm{~m}$, the differences of the mean profiles become much smaller, typically lower than $0.05{ }^{\circ} \mathrm{C}$, except by the lower depths of SACW, where differences also around $0.5{ }^{\circ} \mathrm{C}$ are found. Regarding salinity, at the upper layers, the differences between the profiles are 0.3 (standard deviations are comparable, about 0.1 ), decreasing to less than 0.02 below $250 \mathrm{~m}$. The differences increase between 600 and 

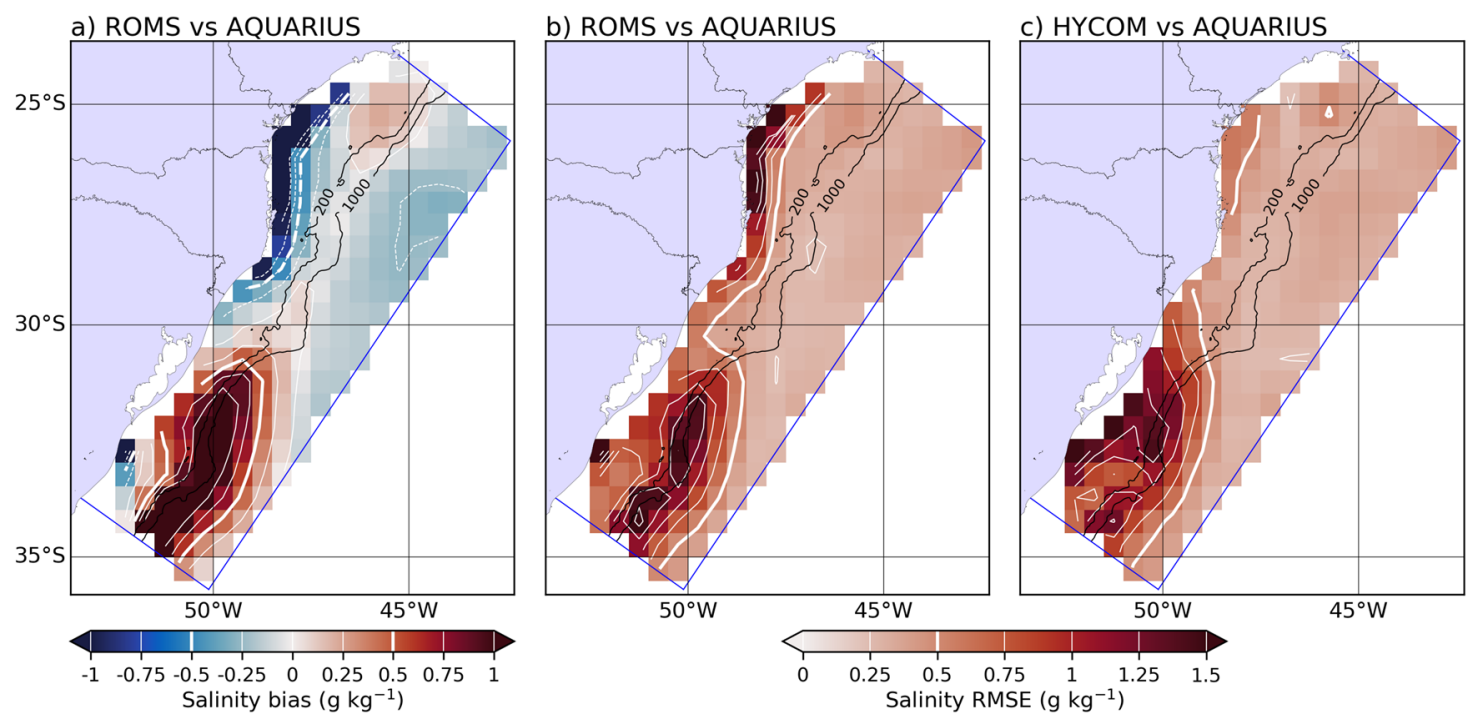

d) Salinity RMSE $\left(\mathrm{g} \mathrm{kg}^{-1}\right)$ : ROMS \& HYCOM vS AQUARIUS

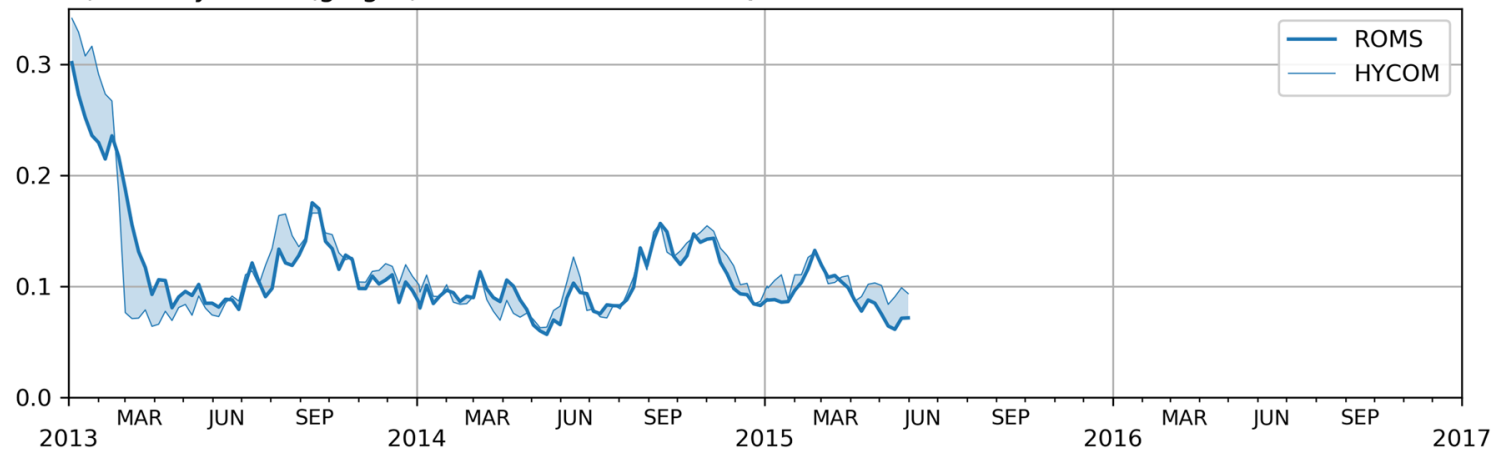

Fig. 4 Comparison of model surface salinity with AQUARIUS. a Bias. b Spatial RMSE. c Spatial RMSE using HYCOM. d Temporal RMSE of ROMS vs AQUARIUS and HYCOM vs AQURIUS

$1200 \mathrm{~m}$ to a maximum of 0.07 by $800 \mathrm{~m}$, and below $1600 \mathrm{~m}$ with a maximum of 0.05 by $1800 \mathrm{~m}$. These temperature and salinity differences are very small, except for the salinity at the upper layers where the mean differences are higher than the standard deviations. This is related to the higher bias in salinity in some regions, in part over the shelf where the CORA is less reliable. To test this, the comparison was done again considering only the locations with depth higher than $1000 \mathrm{~m}$ (Fig. 6c, d). The new comparison shows an almost perfect match for upper layers' temperature mean and standard deviation. For salinity, the maximum differences in the upper layers decreased from 0.3 to 0.23 . The comparison of realistic ROMS model results, also using initial and boundary conditions from HYCOM, with CORA, was done in recent studies for other Brazilian regions and periods, also with positive results (Amorim et al. 2013; Marta-Almeida et al. 2019), reconfirming the suitability of the global HYCOM solution to force regional models in the Brazilian coasts.
Regarding the circulation, the model geostrophic currents were compared with those from AVISO (Archiving, Validation and Interpretation of Satellite Oceanographic data, Pujol et al. 2016). The model geostrophic currents were calculated every day for the wider domain (D1) and seasonally averaged. The AVISO currents were downloaded from the Copernicus database (http://myocean.eu) for the same years with daily periodicity and were also seasonally averaged for comparison with model results. The summer (DJF) and winter (JJA) averages are shown in Fig. 7. In general, it is shown the $\mathrm{BC}$ flowing southward along the slope with intensities around $0.5 \mathrm{~m} \mathrm{~s}^{-1}$. The currents are slightly more intense during the austral summer. The model replicates the AVISO $\mathrm{BC}$ location, intensity, and variability. The poorest comparison is found near the northern boundary where the BC from AVISO currents turns almost $90^{\circ}$ to the left before entering the model domain over the slope. In the model output, the currents close to the northern boundary show a strong meander off the slope and the currents enter the domain 

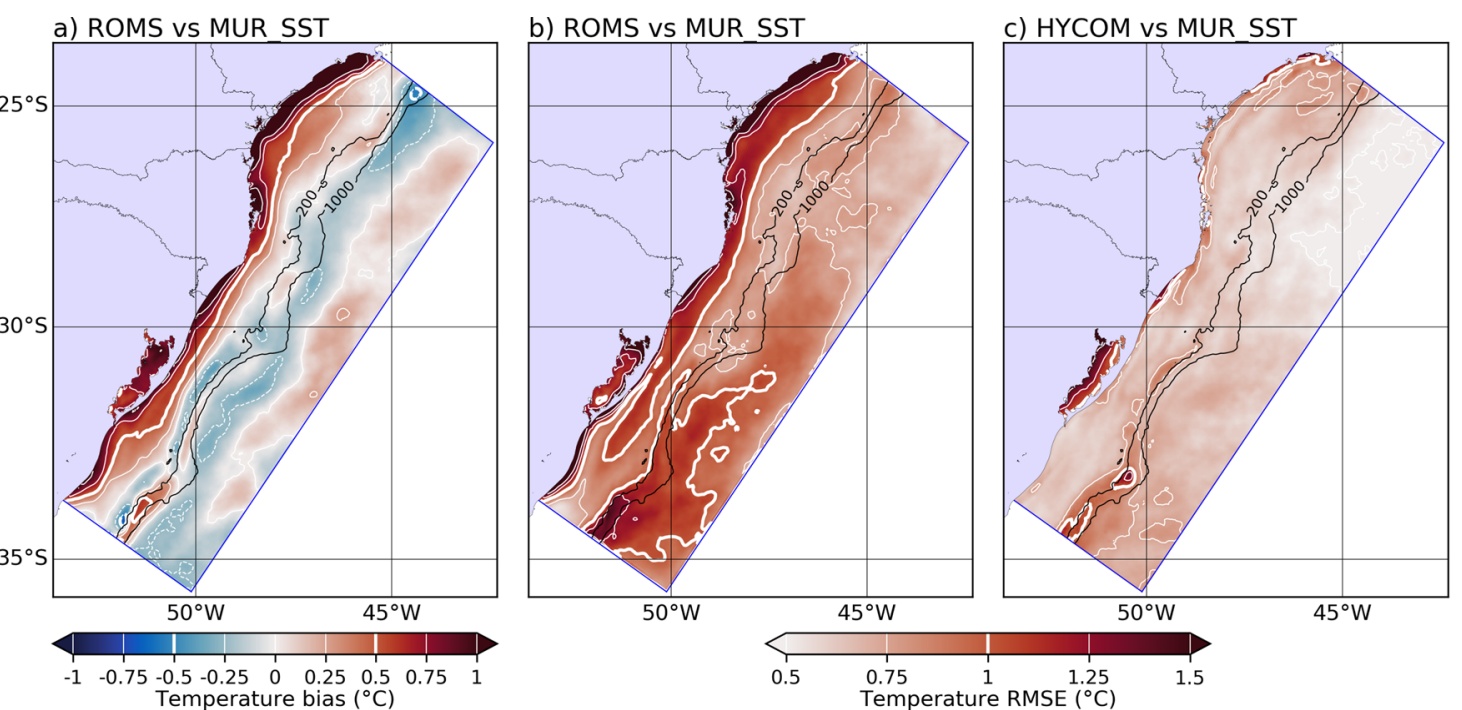

d) Temperature RMSE $\left({ }^{\circ} \mathrm{C}\right):$ ROMS \& HYCOM vs MUR_SST

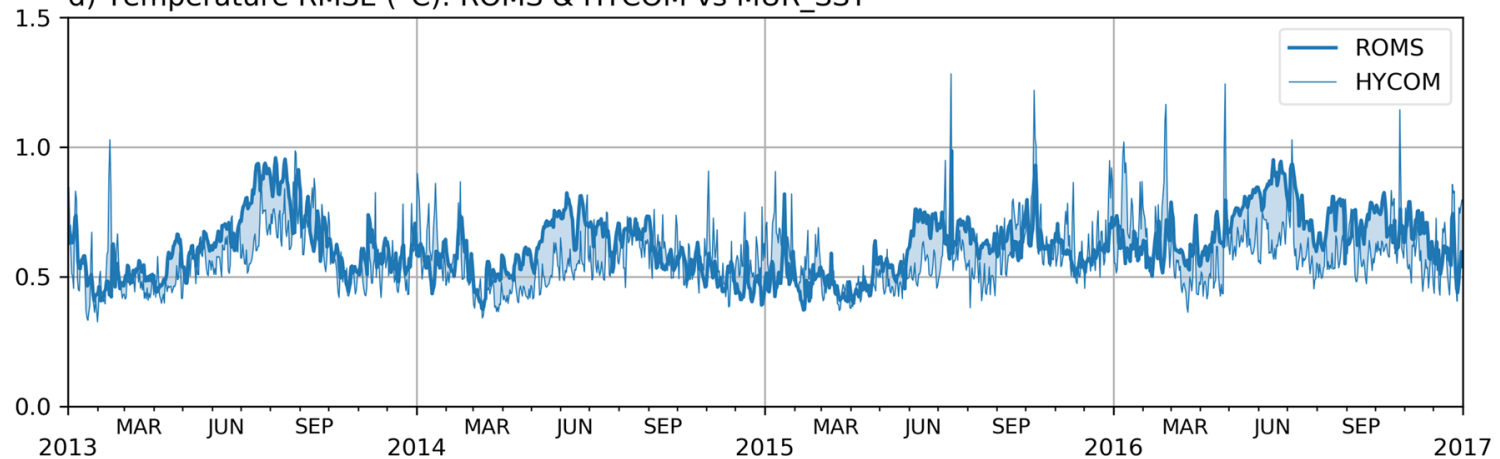

Fig. 5 Comparison of model surface temperature with MUR_SST. a Bias. b Spatial RMSE. c Spatial RMSE using HYCOM. d Temporal RMSE of ROMS vs MUR_SST and HYCOM vs MUR_SST

Fig. 6 Vertical profiles of the time and space averaged temperature and salinity of model results and CORA dataset. The profiles are bounded by the standard deviation of the spatial mean. In the second row, $\mathbf{c}$ and $\mathbf{d}$, the profiles considering only sites at depths higher than $1000 \mathrm{~m}$ are shown
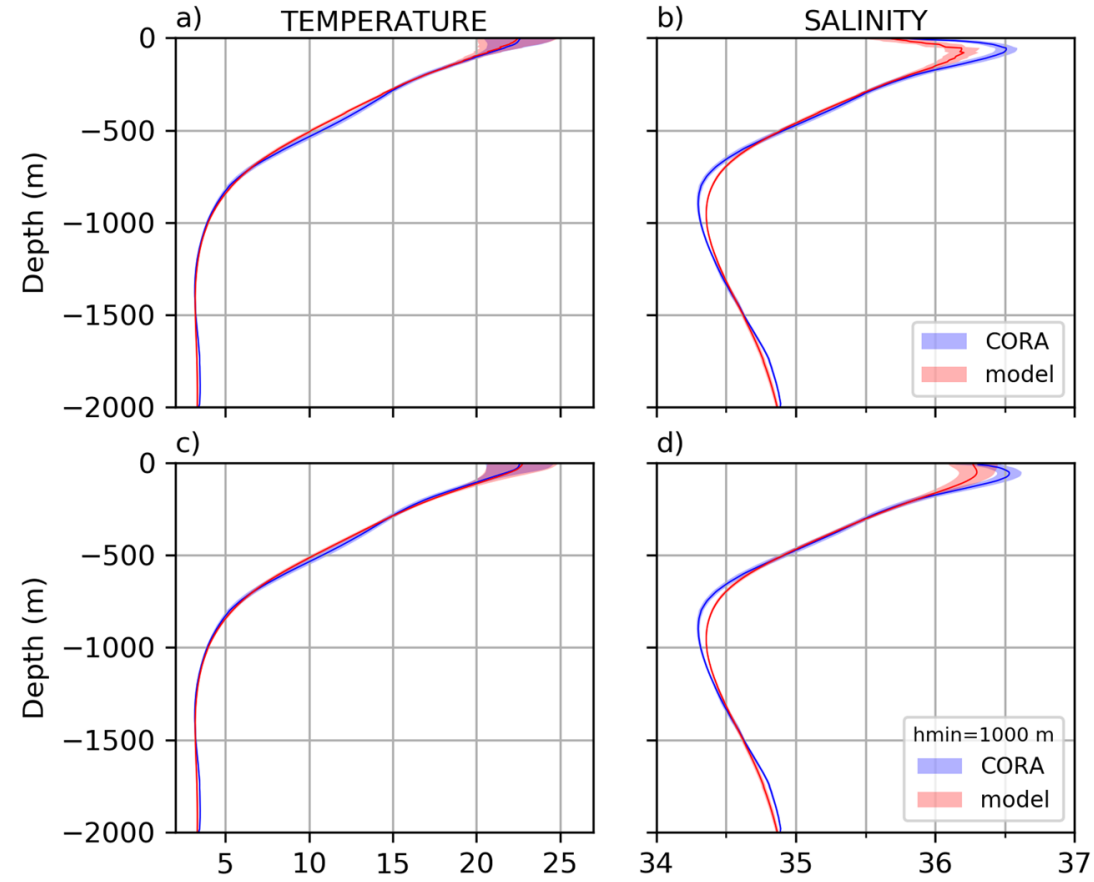
Fig. 7 Comparison of geostrophic currents from AVISO and from model output

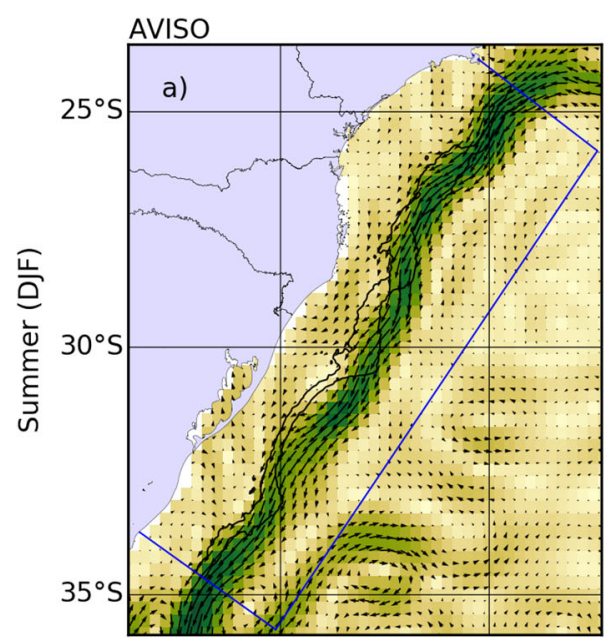

ROMS

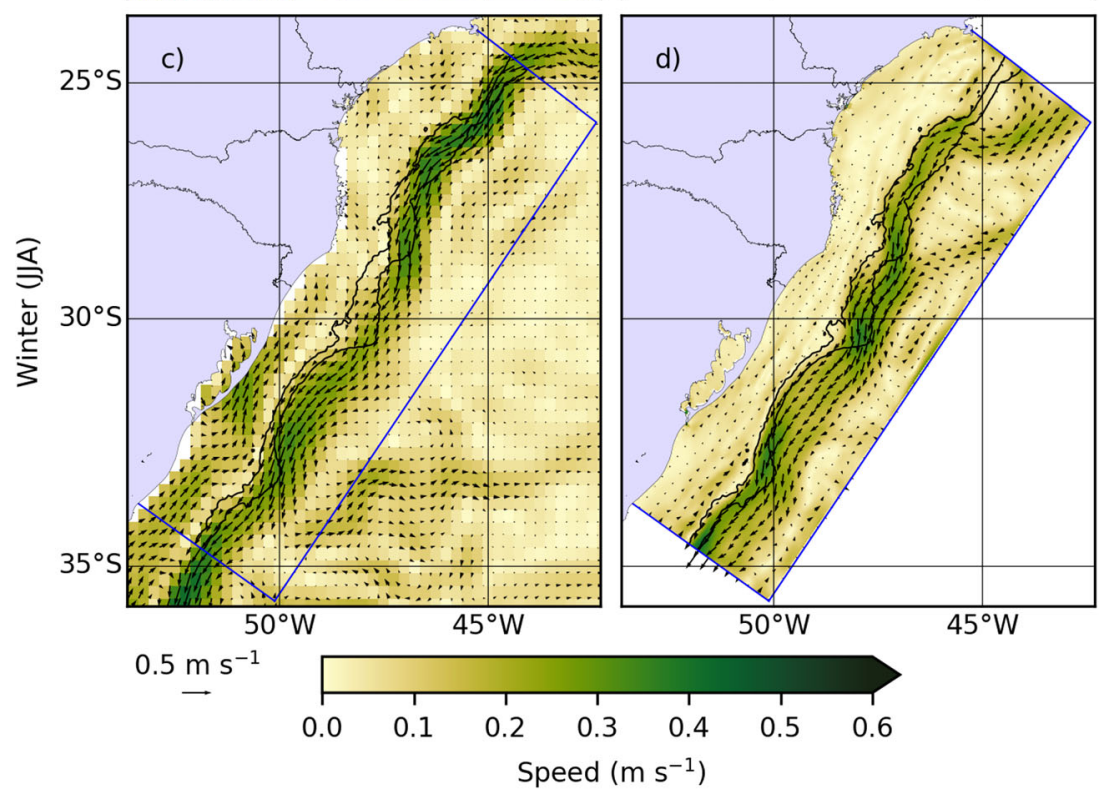

from a different angle. Given the proximity to the model boundary, the horizontal structure of the modelled currents are very influenced by the lateral boundary forcing, i.e., by the results of HYCOM, which may have limitation in this region, around $25^{\circ} \mathrm{S}$. At the southern boundary during the summer, the anticyclonic eddy around the latitude $35^{\circ} \mathrm{S}$ is also reproduced by the model. The BCC, flowing equatorward over the shelf, visible in the AVISO winter currents south of $30^{\circ} \mathrm{S}$, is also present, although with less intensity, in the model geostrophic currents, mainly at the outer shelf.

Finally, the skill of model output on the outer shelf was evaluated comparing with hourly SST and currents measured at three buoys (two buoys at sites with about $250 \mathrm{~m}$ depth and one at about $200 \mathrm{~m}$ ). The location of the buoys is shown in Fig. $1 \mathrm{~b}$ and the model vs in situ data comparison obtained, in terms of correlations, is shown in Table 1. Only the southernmost buoy, located in front of Lagoa dos Patos, measured currents during the simulation period, and only for summer 2014. The currents were measured with an ADCP under $1.5 \mathrm{~m}$ from the surface, every $1.5 \mathrm{~m}$, with good quality data in the upper $20 \mathrm{~m}$. The model output was recorded also every hour and interpolated to the measurement depths. The alongshore currents of both model and observations were then tidally filtered with a 33-h low pass filter. The velocity correlations obtained at the several depths ranged between 0.50 and 0.59 , with an average of 0.55 . The location of this southernmost buoy has a depth of $243 \mathrm{~m}$ and is under influence of the ambient circulation and its mesoscale turbulent features. In addition, the slope is the region most affected by bathymetry smoothing in models with terrain-following vertical coordinates. For these reasons, the correlations obtained for currents are fair. The SST was measured by the three buoys and for a much longer period in two of them (more than two and more than three years). However, the quality of the data is low, having many missing values 
Table 1 Correlation coefficient (corr) between measured and modelled sea surface temperature (SST) and alongshore currents in the upper $20 \mathrm{~m}$ of the water column (ADCP). The location (lon, lat) of the three buoys used are shown in Fig. 1b. The ocean depth at the buoys' sites and the deployment date (init) is also provided. The interval (start, end) and duration of valid ADCP and SST data is given, as well as the percentage of bad values in the interval used. The ADCP correlation corresponds to the mean of the correlations calculated for each depth (every $1.5 \mathrm{~m}$, excluding the upper $1.5 \mathrm{~m}$ )

\begin{tabular}{|c|c|c|c|c|c|c|c|c|c|c|c|c|c|c|}
\hline \multirow[t]{2}{*}{ Buoy } & \multirow[t]{2}{*}{ Lon } & \multirow[t]{2}{*}{ Lat } & \multirow{2}{*}{$\begin{array}{l}\text { Depth } \\
\text { (m) }\end{array}$} & \multirow[t]{2}{*}{ Init } & \multicolumn{5}{|l|}{$\mathrm{ADCP}$} & \multicolumn{5}{|l|}{ SST } \\
\hline & & & & & Start & End & Duration & $\% \mathrm{Bad}$ & Corr & Start & End & Duration & $\% \mathrm{Bad}$ & Corr \\
\hline Santos & -44.928 & -25.273 & 248 & 2012-04 & - & - & - & - & - & 2014-11 & 2015-04 & $154 \mathrm{~d}$ & 61 & 0.92 \\
\hline Itajaí & -47.382 & -28.509 & 192 & 2009-04 & - & - & - & - & - & 2013-02 & 2016-07 & $3.44 \mathrm{y}$ & 14 & 0.96 \\
\hline Rio Grande & -49.875 & -31.582 & 243 & $2002-05$ & 2014-01 & 2014-04 & $102 \mathrm{~d}$ & 0 & 0.55 & 2013-12 & 2016-07 & $2.65 \mathrm{y}$ & 6 & 0.96 \\
\hline
\end{tabular}

and outliers. To overtake this limitation, while keeping the event-scale comparison ability, the SST from the buoys and from the model were 3 days averaged prior to the comparison. And the resulting correlations obtained were high (0.92 and twice 0.96).

\section{Results}

\subsection{Northern region}

The rivers in the northern region (north of Florianópolis, Fig. 2a) have discharges by the end of the year (from September to March) about twice as large as in the drier months around July. The variability is, however, large: the first year, 2013, experienced some weeks of high discharge in June and July, reaching $2000 \mathrm{~m}^{3} \mathrm{~s}^{-1}$, associated with peaks from river Iguape. In 2014, the highest peaks occurred in February, June, and December and were not registered in the other years (except for a small peak in July 2016). The main river is Iguape, with close to $60 \%$ of the discharge in this subregion, located about $350 \mathrm{~km}$ north of Florianópolis (following the coast). In this region, the wind blows mostly towards the coast, converging to the bay (SBB), being predominantly directed southward along the coast (Figs. 8a and 9). The number of episodes of equatorward alongshore wind is variable. While in 2014 and 2015 they occurred only a couple of times per year, in 2016, this was the predominant regime during the winter months, from May to September. Over the slope, the currents are strong and are associated with the BC (Figs. 8a and 9). The flow is predominantly southward with limited sensitivity to wind reversals. Many episodes of northward slope flow events are however not associated with the wind but probably with eddy activity known in the region (Campos et al. 2000; Oliveira et al. 2009). Over the shelf, the currents are much weaker and more correlated with the wind (Fig. 8a).

A core of low salinity, centered at the mouth of river Iguape is present along the year, with salinity values under 34 covering practically all the coastal region of the SBB
(Fig. 9). The northernmost latitude reached by this salinity value occurs in the winter (July) when it extends until the vicinity of Ilhabela. Salinities on the range 35-36 cover most part of the shelf in autumn and winter (April and July), retreating to the inner shelf in the summer. This seasonal variability is not related to wind regime or riverine discharge, but with the seasonal variability of evaporation, as can be inferred from the variability of the sea surface temperature. Temperatures higher than $28^{\circ} \mathrm{C}$ are found at the coast during the summer along the entire SBB. The sea surface temperature decreases in the following months reaching by July values over the shelf ranging from $20^{\circ} \mathrm{C}$ to $22{ }^{\circ} \mathrm{C}$, with an along coast gradient. The temperature starts increasing towards the year-end having already by October values above $23{ }^{\circ} \mathrm{C}$ in a great part of the SBB (north of $\left.27^{\circ} \mathrm{S}\right)$.

Rivers' plume occupies the inner shelf of the SBB along the year (Fig. 10, 1st column). In January, the plume has the greatest southward extension reaching latitudes south of Cape Santa Marta, occupying the central region in front of Florianópolis mostly in January, but also in October, between the isobaths 50 and $100 \mathrm{~m}$. This southward spreading of the plume is consistent with the southward wind regime in the summer months. Due to the orientation of the Santa Catarina Island, the meridionally flowing freshwater increases the separation from the island towards the south. This separation also seems to be associated with the presence of the plume from the southern region (Fig. 10, 1 st line-see 1 st and 4st columns). Model results show no evidence of the plume from the northern region being able to reach coastal locations around Florianópolis, namely the bay of river Tijucas and the North and South Bays (the bays between the Santa Catarina Island and mainland).

The vertical transects of salinity, temperature, current speed, and dye concentration further clarifies the seasonal variability of the region (Fig. 11, 1st column). Salinity values above 36 are found at the shelf in January, under the plume waters at the inner shelf and reaching the surface at the middle shelf. This salinity band is displaced offshore in the following months, being almost absent from the 
Fig. 8 Wind and currents time series at sites located in the northern (a), central, in front of Florianópolis (b), and southern region of the domain (c) and (d). The locations are shown in Fig. $1 \mathrm{~b}$ as red dots for currentson the isobaths 50 and 500-and black dots for wind-on the isobath 100. For each region, (i) the wind (90 days low-pass filtered), (ii) the alongshore component of the wind (30 days low-pass filtered, red/black means positive

(equatorward)/negative), (iii and iv) and the currents on the 50 and $500 \mathrm{~m}$ isobaths (30 days low-pass filtered) are plotted

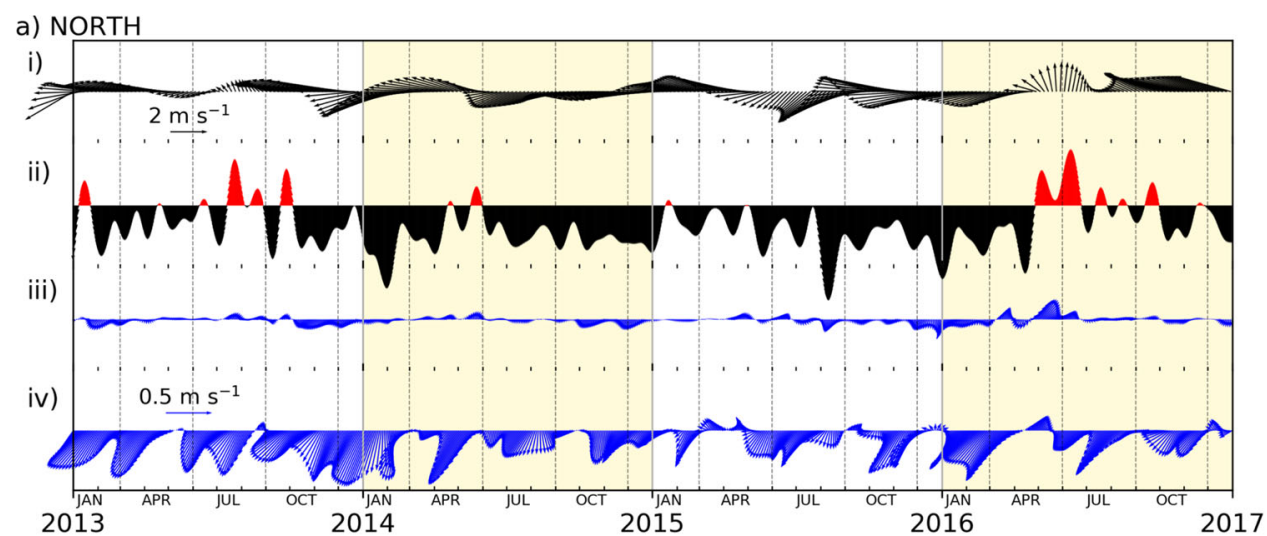

b) CENTRE

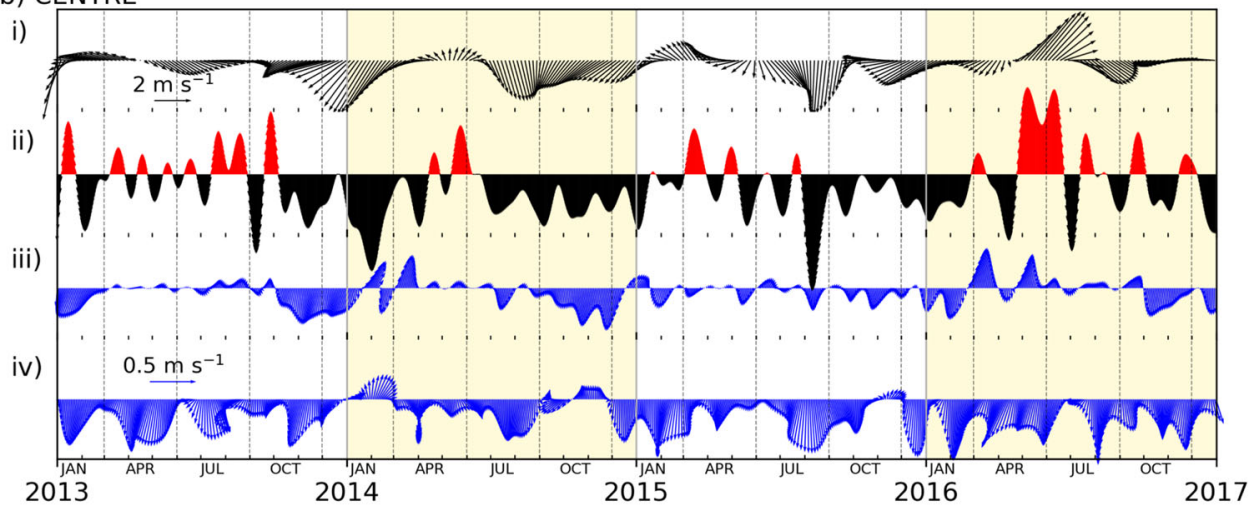

c) SOUTHI

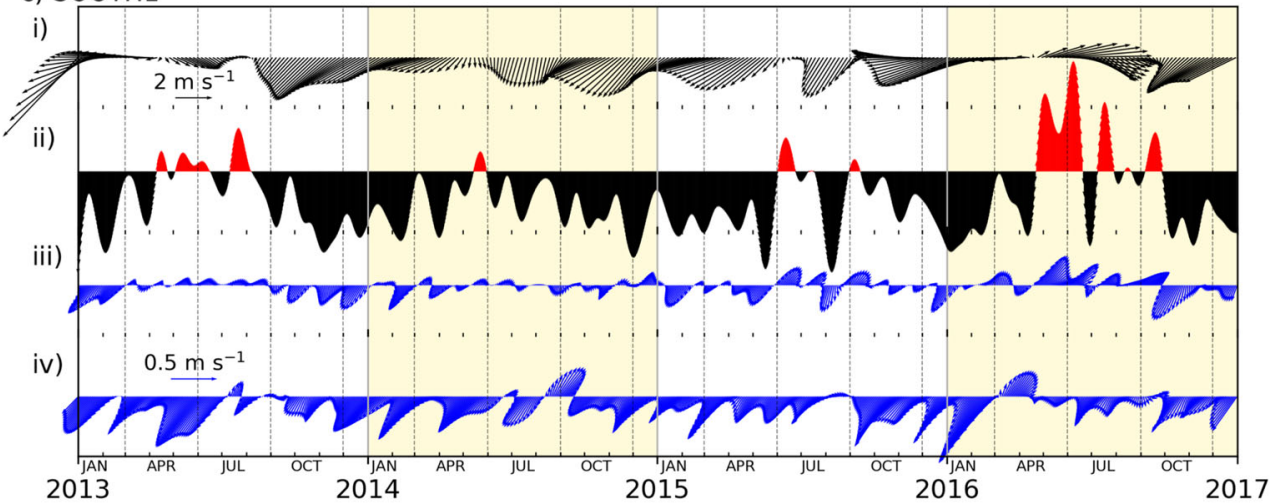

d) $\mathrm{SOUTH} 2$

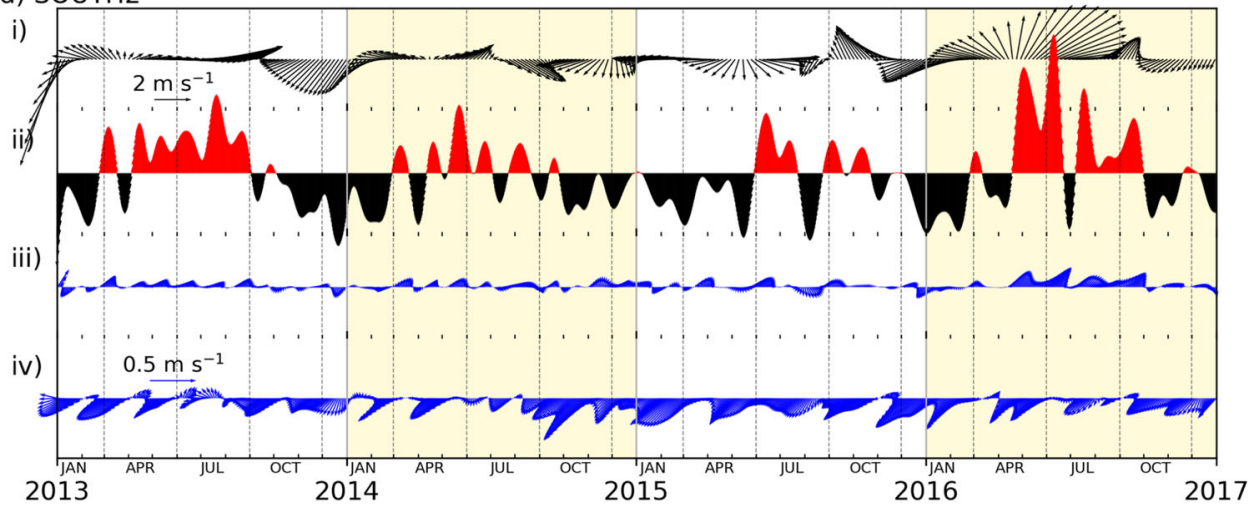



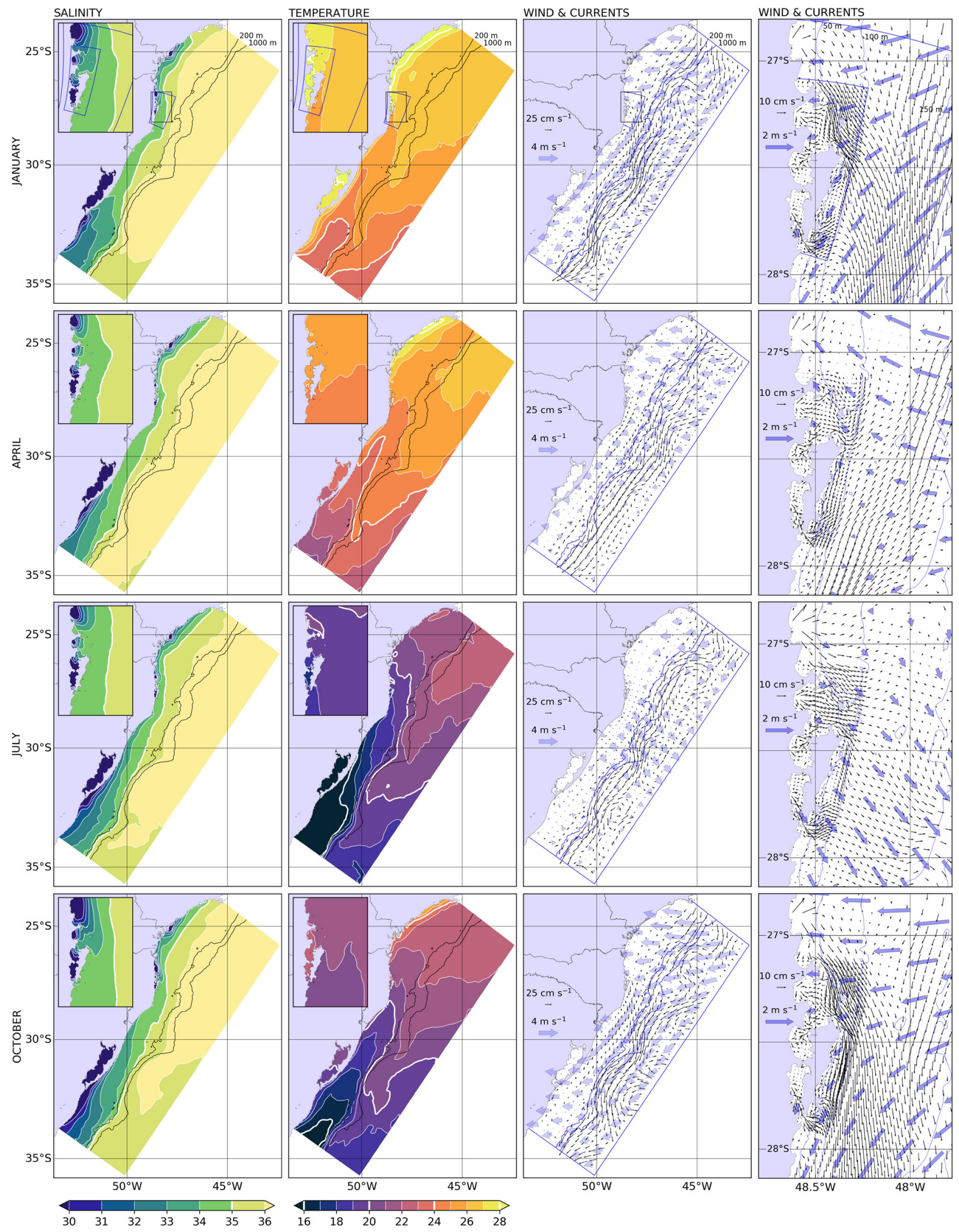

Fig. 9 Seasonal variability of surface temperature $\left({ }^{\circ} \mathrm{C}\right)$, surface salinity, wind and surface currents. The central month of each season is shown. The right column is a zoom of the 3 rd column around Florianópolis 

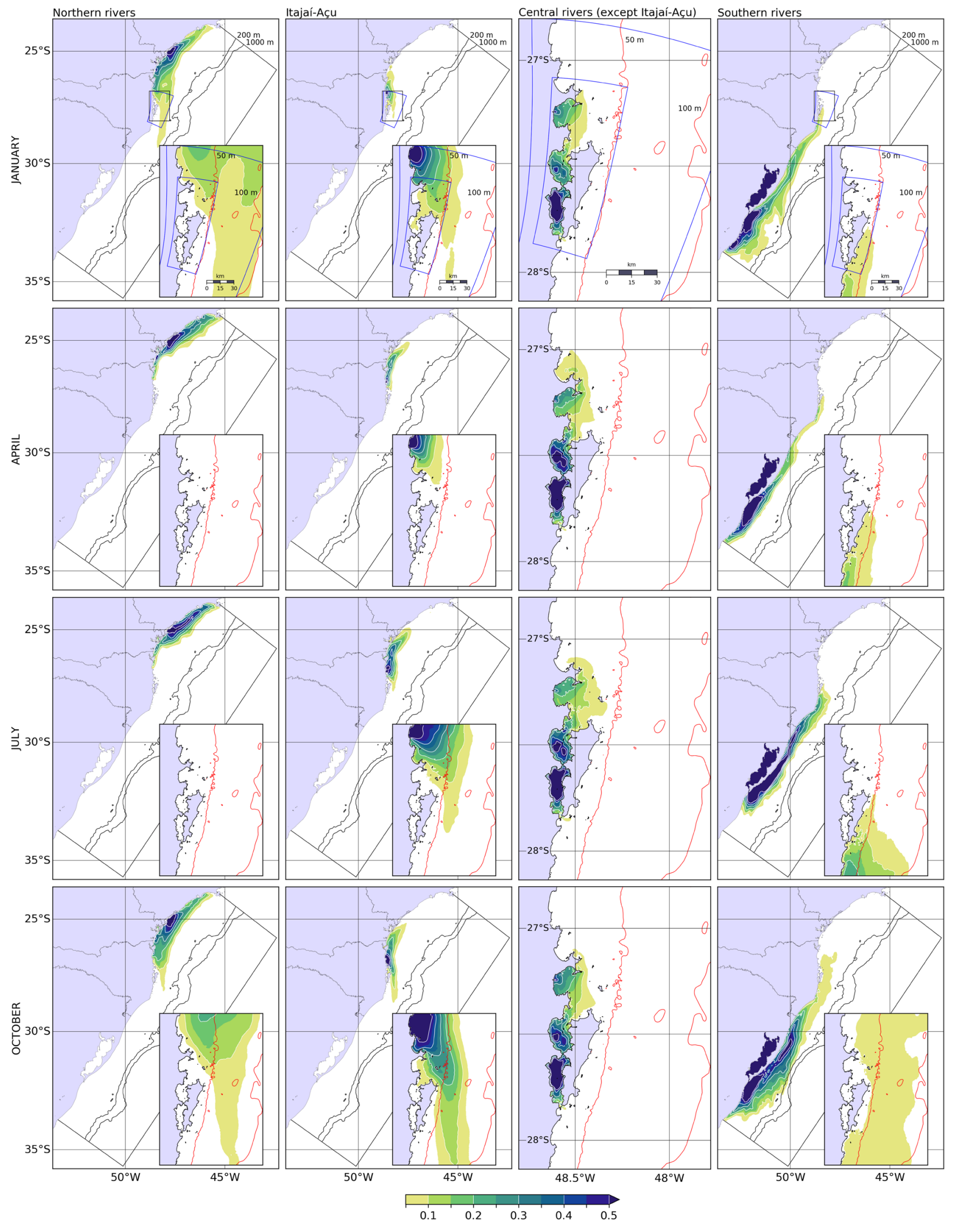

Fig. 10 Seasonal variability of the rivers' freshwater depth $(\mathrm{m})$. The central month of each season is shown. In black are shown the isobaths 200 and $1000 \mathrm{~m}$ and in red the isobaths 50 and $100 \mathrm{~m}$ 
shelf by July. The higher salinity values are transported southward by the $\mathrm{BC}$ on the shelf break with maxima speeds near the surface above $0.3 \mathrm{~m} \mathrm{~s}^{-1}$. The temperature stratification at the shelf is higher in January $\left(16-28{ }^{\circ} \mathrm{C}\right.$, with plume temperature above $24^{\circ} \mathrm{C}$ ) and is lower in July $\left(16-22{ }^{\circ} \mathrm{C}\right)$, when the upper $70 \mathrm{~m}$ is well mixed $\left(20-22^{\circ} \mathrm{C}\right)$. Note that in Fig. 11 the temperature contours are shown mostly every $5{ }^{\circ} \mathrm{C}$ for clarity and this analysis is based on contours with higher resolution, not shown. In April (autumn), the equatorward current contour of $0.05 \mathrm{~m} \mathrm{~s}^{-1}$ is visible. The plume is thinner in the summer (January) with a maximum depth of $25 \mathrm{~m}$, while by July, it reaches the bottom at 45-m depth. This vertical variability of the plume depth is associated with the plume displacement southward during the summer. The offshore extent of the plume does not however vary significantly throughout the year. The vertical stratification of the plume offshore, thus, decreases in the winter season when the interaction with the bottom is higher. The plume is illustrated by the contours 0.005 and 0.02 of dye concentration, using the sum of all dyes. These contours follow very well the contours of salinity, i.e., in this region, the freshwater is highly correlated with dye concentration. Local river discharge is thus the main driver of buoyant waters in the inner shelf.

\subsection{Around Florianópolis}

The rivers discharging in the central region have the largest peaks of the whole domain, reaching values higher than $4000 \mathrm{~m}^{3} \mathrm{~s}^{-1}$, Fig. $2 \mathrm{~b}$ (in reality this may not be true since about $95 \%$ of the discharge in the southern region, with a much higher mean discharge, is climatological, and its daily values may also have strong discharge events). This region is dominated by river Itajaí-Açu with $83 \%$ of the discharge. The months of higher discharge are variable but occur typically between June and October. The wind is more intense than in the northern region and has also stronger northward periods (Fig. 8b). While in 2013, the northward winds occurred in several periods until October, in the other years they took place mostly during the autumn. The stronger northward winds originate stronger northward currents at the inner shelf, much stronger than in the region
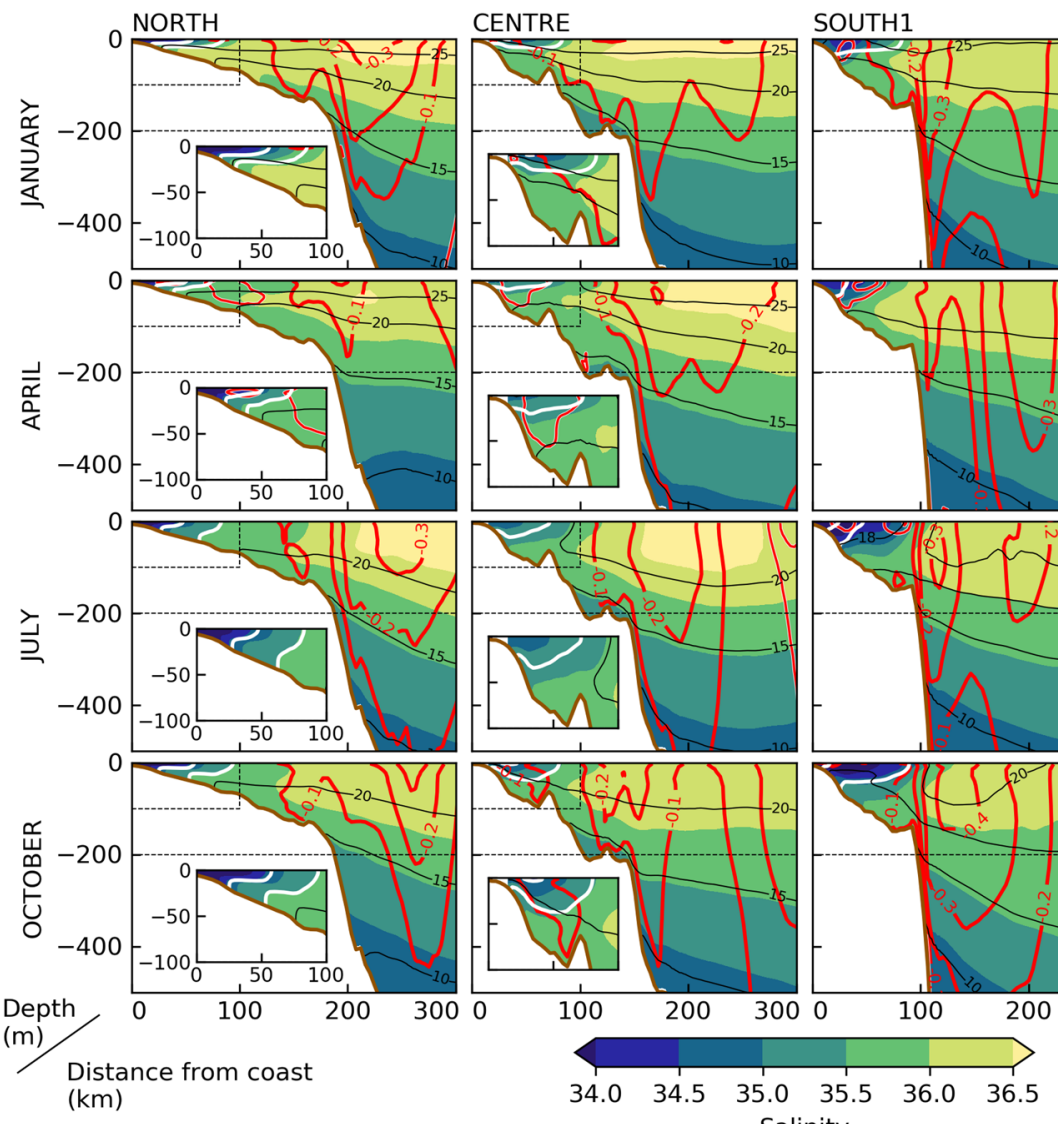

SOUTH1
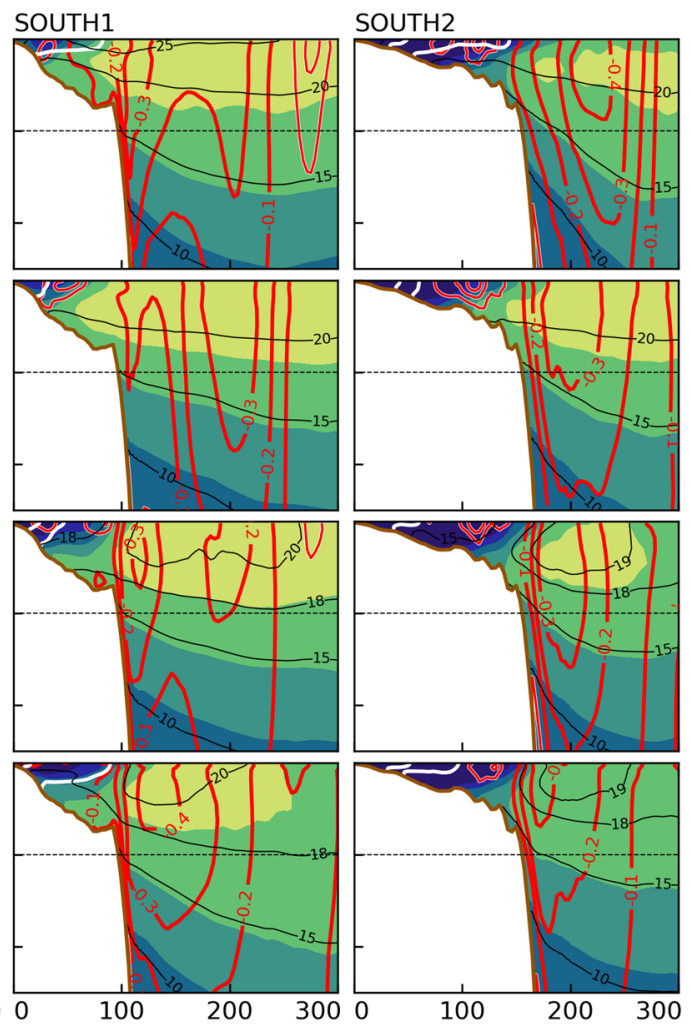

Salinity

Fig. 11 Vertical profiles of salinity in four transects along the coast (the locations are illustrated in Fig. 1b). The white contours represent the passive tracers concentration of 0.005 and 0.02 (sum of all dyes). The red contours show the poleward alongshore currents. The light red contours represent equatorward currents of $0.05,0.1$ and $0.15 \mathrm{~m}$ $\mathrm{s}^{-1}$. Temperature is shown as black contours. The NORTH and CENTRE panels include a zoom near the coast (100 m depth by $100 \mathrm{~km}$ of distance from coast) 
north of Florianópolis. While still weaker than that at slope, the shelf currents here are more intense (than in the northern region) and in many periods comparable to the slope currents. The seasonal surface maps of wind and currents (Fig. 9, right panels) show the wind converging to the coast at Florianópolis during the spring and summer months (October and January), associated with strong southward alongshore currents. During the autumn, the wind turns from northeast to southeast and the shelf currents reverse, moving equatorward. In the winter (July), the average wind blows from the northwest with spatially variable intensity, resulting in also spatially variable, but weak, currents, mainly diverging from the coast, moving offshore and southward over the shelf.

Salinity (Fig. 9, left panels) shows very little seasonal variability, with values of 34-35 in the inner shelf, except in the vicinity of the rivers, and 35-36 in the outer shelf, year-round. Surface temperature oscillates $3{ }^{\circ} \mathrm{C}$, from $19-20{ }^{\circ} \mathrm{C}$ in the winter to $22-23{ }^{\circ} \mathrm{C}$ in the summer. The plume of Itajaí-Açu (Fig. 10, 2nd column) has its greater extension northward in the winter (July, $25^{\circ} \mathrm{S}$ ) and southward in October, reaching the latitudes of Cape Santa Marta one season before the plume from the rivers north of Florianópolis. The separation from Santa Catarina island, as the plume disperses southward, is also observed (analogously to the northern rivers' plume). During the spring, the plume enters the bay of Tijucas, and by the summer, it enters the North Bay, though in a very small amount. January has the lowest area occupied by the plume, probably due to the strong inner shelf currents by yearend (Fig. 8b, ii) and also due to the river discharge smaller than during the winter. The other three rivers of the central region (Tijucas, Biguaçu, and Cubatão do Sul, Fig. 10, 3rd column) are very regional, with a total mean discharge of $93 \mathrm{~m}^{3} \mathrm{~s}^{-1}$. Biguaçu, in the North Bay, and Cubatão do Sul, in the South Bay, with very low discharge $\left(33 \mathrm{~m}^{3}\right.$ $\mathrm{s}^{-1}$ in average, together), have influence only locally in the bays they drain into. Tijucas, the largest of the three rivers (average discharge of $61 \mathrm{~m}^{3} \mathrm{~s}^{-1}$ ), occupies the coastal region from the Bay of Tijucas to the north of Santa Catarina Island. In the winter, the currents off coast disperse the plume a few km until the Arvoredo reserve (see Fig. 1c).

The vertical transects (Fig. 11, 2st column), illustrating the variables west of Santa Catarina Island, show the small seasonal variability of the shelf and slope salinity. Near the island, the salinity is higher than in the northern region, in the range 34.5-35.5 in all the seasons except autumn (April) when it has values of 35-35.5. The shelf temperature ranges $14-28{ }^{\circ} \mathrm{C}$ in January, with plume temperature above $22{ }^{\circ} \mathrm{C}$. This stratification decreases along the months, and in July, the temperature range becomes $14-22{ }^{\circ} \mathrm{C}\left(14-20{ }^{\circ} \mathrm{C}\right.$ at the inner and middle shelf). The equatorward current (contour of $0.05 \mathrm{~m} \mathrm{~s}^{-1}$ ) in April is also visible in this region. The dye contour 0.02 is practically absent all year. In this transect, the freshwater comes from the rivers of the northern region, from Itajaí-Açu, and from the southern region (possibly La Plata and the rivers included in the model south of Florianópolis). And indeed, from the maps of the spatial distribution of dyes (Fig. 10), April has the lowest presence of freshwater in the central region, with contributions from the southern rivers only. Being under the influence of rivers discharging away from Florianópolis justifies the higher salinity in this region, and also justifies the small interaction of the plume with the topography. On the other hand, the dye contour 0.005 does not match the contours of salinity as closely as in the northern region, which may be associated with air-sea fluxes as the plume sources are far away from the transect. It may be also associated with the presence of freshwater from sources not included in the domain, i.e., the La Plata river plume.

\subsection{Southern region}

In the southern region, the highest discharge takes place from June to October, similarly to the central region. Eightysix percent of the discharge in this region occurs in Lagoa dos Patos (rivers Guaíba, Camaquã and São Gonçalo), which is connected to the ocean about $600 \mathrm{~km}$ south of Florianópolis. The region has important spatial variability of the wind. The wind time series at the shelf by the north of Lagoa dos Patos (on the transect South1 in Fig. 1b) has the strongest southward regime of the whole domain and has few northward periods, except in 2016 with strong northward wind events between mid-April to September (Fig. 8). In front of Mirim Lagoon (South2), the southward wind is much weaker and the northward wind is much stronger and very common in the autumn, winter, and spring. At both locations, the inner shelf currents respond to the wind relaxation and inversion. As happens through the domain, the inner shelf currents are weaker than over the slope, where a couple of strong current reversion events (moving northward) are observed and not associated with northward wind events. They may be associated with the BMC influence in the origin of the BCC (Palma et al. 2008; Dalbosco 2019).

Freshwater with salinity values lower than 30 is found around the mouth of Lagoa dos Patos (Fig. 9). Low salinity waters are however present over the shelf in the south of the domain and in part provenient from the La Plata plume through the southern boundary. This low salinity band disperses northward during the winter, due to the northward wind regime, until the latitude of Cape Santa Marta. It then retracts southward in the summer months (e.g., Piola 2005; Soares et al. 2007b) until the mid-latitude of Lagoa dos Patos. South and in front of Lagoa dos Patos it occupies the whole shelf, narrowing north until the coast. Sea surface 
temperature also oscillates seasonally due to the different wind regimes together with the seasonally variable surface thermal fluxes. In July, waters colder than $16{ }^{\circ} \mathrm{C}$ extend north until close to $30^{\circ} \mathrm{S}$. By October, the $16^{\circ} \mathrm{C}$ isoline has already retracted to the latitudes of Mirim Lagoon $\left(\sim 33^{\circ} \mathrm{S}\right)$. Temperature continues increasing during the summer to values of $23-26{ }^{\circ} \mathrm{C}$ in January. The shelf waters contrast with the warmer $\mathrm{BC}$ moving southward over the slope.

The plume of the southern rivers (Fig. 10, right panels) disperses north until the latitude of Florianópolis the whole year, but in greater volume during the winter season (July). The region in front of Tijucas Bay, the North Bay, and the South Bay of Florianópolis is however not affected by this plume. Also, in July, the plume has the smallest southward extension, reaching about $33^{\circ} \mathrm{S}$, while during the other seasons it reaches the south model boundary. The plume offshore extension follows the upwelling/downwelling wind regime, with the plume occupying a large part of the shelf south of $30^{\circ} \mathrm{S}$ during spring and summer (upwelling regime), and confined to the inner and middle shelf during autumn and winter (downwelling regime). This seasonal response of river plumes on SB has been described in Soares and Möller (2001) and Soares et al. (2007b), which focused on plumes from Rio de la Plata and Lagoa dos Patos and its dispersion on the shelf south from $30^{\circ} \mathrm{S}$.

The vertical transects (South1 and South2, 3rd and 4th columns in Fig. 11) show that while the seasonal variability of ambient salinity is small, the salinity and dye concentration near the coast are very variable in the southern region. At South1, waters with salinity values lower than 35.5 are more confined to the coast in the summer and expand offshore through the shelf during the winter. The dye concentration, however, does not follow this pattern. In January, the dye occupies the shelf (at the surface), which indicates the riverine waters moving south in the summer already lost part of their freshwater characteristics, probably because of spending many months away from the discharge location. On the other hand, during the winter the amount of fresh water is much higher than the amount of dye, showing the influence of the low salinity waters from La Plata moving north during the winter wind regime. The depth reached by the plume from local rivers (dye) shows low variability along the year, contrarily to its offshore extent, in opposition to what happens in the northern region. The temperature stratification varies between 16 and $26^{\circ} \mathrm{C}$ in January (with plume waters of SB rivers above $22^{\circ} \mathrm{C}$ ) and 16 and $20^{\circ} \mathrm{C}$ in July, when colder waters are present in the upper $50 \mathrm{~m}$ of the shelf $\left(16-18{ }^{\circ} \mathrm{C}\right)$. The equatorward BCC is stronger in April, and absent in October.

At South2 (Fig. 11, 4th column), closer to the southern boundary, the difference between low salinity and dye concentration contours is even larger than that at South1. At these latitudes, water with salinity lower than 34 covers most of the shelf year-round but with a greater extent in the winter, associated with the northward transport of freshwater from the southern boundary. In July, however, the dye is almost absent at the latitudes of the South2 transect. In the summer, the extent of dye concentration is closer to the extent of the low salinity waters because of the freshwater at the shelf, originated from local rivers, moving south with the summer wind regime. The temperature stratification at the shelf ranges $15-24{ }^{\circ} \mathrm{C}$ in January (dye plume waters above $22{ }^{\circ} \mathrm{C}$ ) and $14-16{ }^{\circ} \mathrm{C}$ in July in most of the shelf $\left(15-18^{\circ} \mathrm{C}\right.$ at the outer shelf). Flowing along the $100 \mathrm{~m}$ isobath, the $\mathrm{BCC}$ is more intense in this transect.

\subsection{La Plata river plume}

A Lagrangian approach was used to assess the possible migration northward of waters near the southern boundary, under the influence of the La Plata river plume. Floats were continuously released over the shelf and slope at the south of the model domain and its position was followed through the entire simulation period. The result is shown in Fig. 12. The northward migration pattern is variable along the years, but the higher latitudes are consistently reached during late winter/early spring. In 2014 and 2015, the floats reached latitudes around $30^{\circ} \mathrm{S}$, but in 2013 and 2016, they reached the region of Florianópolis (2013) and latitudes north of river Paranaguá (2016, 25.5 ${ }^{\circ}$ S). In 2013, Florianópolis was reached about 180 days after release, while in 2016, it was reached twice as fast, in about 90 days. The northernmost latitude in 2016 was reached in June, 100 days after release. In this year, the northward migration was very fast and until higher latitudes due to the strong northward wind in the autumn and winter. This means the southern waters spent 3 to 6 months migrating northward. The southernmost locations (i.e., the percentiles $90 \%$ and $95 \%$ of the northernmost floats) is reached by the summer months and the migration north restarts by the end of summer/early autumn, when the age of the particles is lower than 50-60 days. When the floats start migrating back southward, their age continues increasing and then decreases rapidly as the water mass moving south mixes with the southern waters, increasing the number of younger floats in the mean age percentile $90 \%$.

\section{Discussion}

The online nesting modelling approach used in this study resolved a wide range of spatial scales in the same configuration. The largest domain covers SB and most of the SBB (near $1500 \mathrm{~km}$ along the coast), while the smaller domain covers the coastal region around Florianópolis with resolution reaching $150 \mathrm{~m}$. Such very high resolution is 

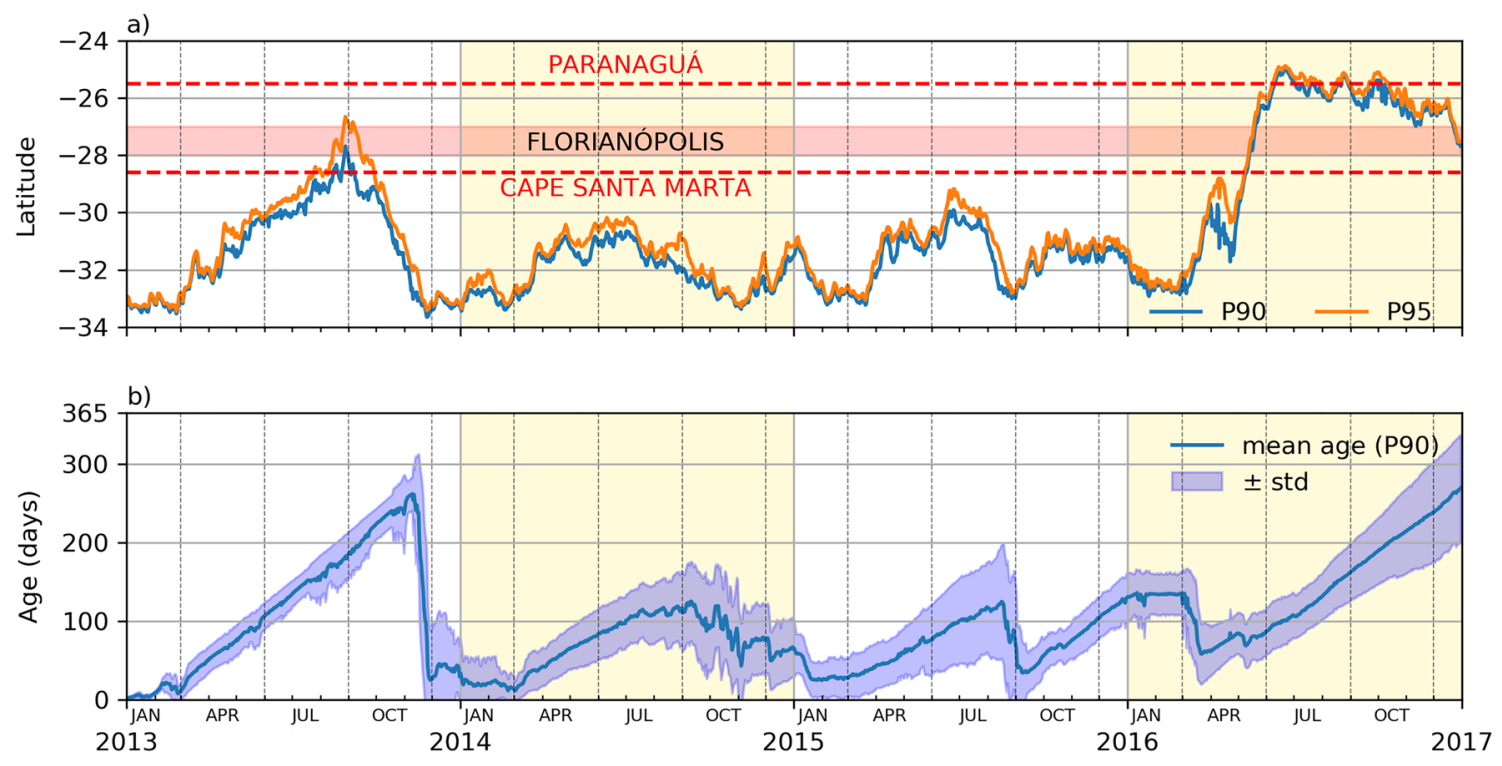

Fig. 12 a Percentiles $90 \%$ and $95 \%$ of the northernmost latitude reached by the Lagrangian floats released near the southern model boundary; the latitudes of the Florianópolis region $\left(27^{\circ} \mathrm{S}-28^{\circ} \mathrm{S}\right)$ are highlighted. b Mean age of the northernmost percentile $90 \%$ floats, bounded by the standard deviation

needed to resolve the region between the Santa Catarina island and the mainland (North Bay and South Bay), as it includes narrow regions, including a 400-m-wide channel. This configuration, thus, makes it possible to simulate very small-scale bathymetric and coastal features in one selected region, along with realistic ambient circulation and mesoscale variability. And, in particular, it possibilitates to study the influence of river plumes in Florianópolis, including those from rivers far away.

The river plumes of the SBB and SB are in general confined to the inner shelf, except the freshwater from Lagoa dos Patos which disperses through the shelf south of $30^{\circ} \mathrm{S}$ during the spring and summer, as already put forth in the numerical simulations by Soares et al. (2007b). While affected by the riverine discharge, the plumes are mostly controlled by wind time and space variability. The plumes behave as buoyant surface advected plumes and as intermediate plumes (Yankovsky and Chapman 1997), spreading and mixing with seawater over the shelf by the influence of Coriolis and baroclinic pressure gradients, dispersing the plumes equatorward, and seasonal wind (e.g., Fong and Geyer 2002; Lentz 2004; Whitney and Garvine 2005; Horner-Devine et al. 2015). The interannual variability of the interaction with the bottom depends on the region, but is stronger during the winter season, when the vertical stratification of the plume front is smaller. The validation section showed that the model configuration simulates realistically the warm and salty BC on the slope (Stramma et al. 1990) and its seasonal variability. BC is more intense in the summer and its separation from the coast (at the BMC) is displaced to the south from spring on
(Olson et al. 1988). As a shelf/inner shelf feature in a region with the strong and persistent large-scale BC flowing over the slope, the river plumes are isolated from the oceanic mesoscale dynamics. This shielding exerted by the slope current appears to be stronger than in other regions, like the Western Atlantic Iberia, where offshore induced cross-slope transport is possible (Bettencourt et al. 2017). Nevertheless, more studies are needed to evaluate the seasonal and eventscale influence of offshore dynamics on the shelf and on the river plumes in the region.

North of Florianópolis, in the SBB, the wind is predominantly southward, with few episodes of northward wind, and the shelf currents are weak. The freshwater plume extends southward from the north of the domain (Ilhabela) and reaches Florianópolis during the spring and summer. During the summer, it disperses further south until the Cape of Santa Marta, when the interaction with the bottom is lower. Eddies associated with the BC may influence the outer shelf and slope, but not the local river plumes.

The central region around Florianópolis is under the influence of its largest river, the Itajaí-Açu. Its smaller area of influence occurs in the summer because of the strong inner shelf currents and because of the lower river discharge. The freshwater from this river reaches Cape of Santa Marta in the spring, one season earlier than river plumes of the northern region. While no river plumes of the northern and southern regions are able to reach the coastal region of Florianópolis (Tijucas Bay, North Bay and South Bay), the shelf in front of the Santa Catarina Island is influenced by rivers from both the northern and southern regions. This influence has a minimum in the autumn when the 
contribution to the fresh water comes only from the south. The wind has strong northward periods, mainly during the autumn, stronger than in the northern region and the north of the southern region. In this season, the circulation over the shelf reverses becoming northward.

The region south of Florianópolis (SB) is influenced by the river discharge from Lagoa dos Patos and by the presence of the La Plata river plume. The wind spatial variability in the region is high. While by the north of Lagoa dos Patos the wind is stronger and mainly southward, with few northward periods, in front of Mirin Lagoon the northward periods are common from autumn to spring. The upwelling/downwelling seasons (spring and summer/autumn and winter) clearly affect the plume of SB rivers, extending it over the shelf (south of $30^{\circ} \mathrm{S}$ ) or confining it to the inner and middle shelf. While situated $600 \mathrm{~km}$ south of Florianópolis, the plume from Lagoa dos Patos (mostly, as it represents close to $90 \%$ of the discharge in SB) reaches Florianópolis in all the seasons, more efficiently in the winter. BCC carrying cold and fresh waters is very clear along the $100 \mathrm{~m}$ isobath in the simulation results (geostrophic velocities, Fig. 7 and transects, Fig. 11) to the south of the domain in autumn (April) and winter (July), as expected from the literature (Zavialov et al. 2002; de Souza and Robinson 2004; Palma et al. 2008).

The Lagrangian floats used to access the northward influence of the La Plata river plume show the waters near the boundary of Brazil-Uruguay have a variable northward dispersion pattern. The northernmost locations are reached by the late winter/early spring. The northward migrations take 3 to 6 months and the floats are able to reach regions north of Florianópolis (located at $27-28^{\circ} \mathrm{S}$ ). In the last year of simulation, the floats dispersed until north of the mouth or river Paranaguá $\left(\sim 25.5^{\circ} \mathrm{S}\right), 230 \mathrm{~km}$ north of Florianópolis. This result shows the importance of the La Plata river plume, mainly in SB, where a poor match between the low salinity shelf waters and local riverine dye concentration (of the local rivers) was obtained.

\section{Conclusion}

A modelling configuration was created for the SBB (South Brazilian Bight) and SB (South Brazil) regions. The model was forced with realistic surface and lateral forcing, with river discharges and with tides. Three 2-way nested domains were employed in order to obtain very high resolution in the Florianópolis region, which was covered by the third domain. This region has small-scale features like islands and channels and was resolved with a resolution of about $150 \mathrm{~m}$. Model validation was done against observational datasets of surface and vertical profiles of temperature and salinity, altimetric geostrophic currents, and time series of surface temperature and upper layer ADCP currents, measured by three buoys along the domain on the shelf break. The validation shows the model describes realistically ambient circulation, namely the Brazil Current (BC), and consequently shelf circulation, including the Brazilian Coastal Current (BCC).

In order to study the dynamics of river plumes and to evaluate possible intrusions of riverine waters from distant sources in the Florianópolis region, several dyes were released together with the river discharges. The dye concentration was then used to calculate the depths of the riverine freshwater, and the resulting regions affected by the plumes were studied in terms of seasonal variability. To access possible migrations of waters from the southern region, under influence of the La Plata river plume, a Lagrangian approach was used in which a set of floats was released every day at the surface on the shelf and slope close to the southern model boundary (near the Brazil-Uruguay boundary). The latitudinal variability of the floats was then analyzed along the simulation, as well as the age of the northernmost floats. The results depict the migration region, duration, and periods of the southern waters.

The analysis of the model output shows that the plumes originated from rivers in the SBB and SB are in general restricted to the inner shelf. The exception is the plume from the rivers of Lagoa dos Patos which disperse over the shelf south of $30^{\circ} \mathrm{S}$ during the austral spring and summer. The results also show that offshore circulation does not interact with the shelf plumes due to the shielding effect of the BC, flowing over the slope along the domain.

This work highlights the importance of the time variability of the river discharge and, mainly, of the time and space variability of the wind forcing in the fate of the freshwater plumes. The presence of a freshwater belt with salinities lower than 35, along the SBB and SB yearround, also highlights the importance of considering the rivers of the region, even the smaller ones. These have been disregarded in modelling configurations, typically more focused on the discharge of La Plata and Lagoa dos Patos. The low salinity waters along the coast generate baroclinic pressure gradients which force equatorward circulation. This mechanism seems to complement the wind forcing on the shelf circulation and dispersion of the river plumes in the SBB and SB regions. By studying the rivers individually or in regional groups, using passive tracers, the magnitude of the several plumes and their interaction become more evident. The dispersion patterns demonstrate the influence of the presence of other plumes, in particular (i) the Florianópolis coastal region is not reached by distant rivers, in part because of the presence of local plumes (Fig. 10, 1 st and 4th columns); (ii) the dispersion south of the plume from the northern rivers and from Itajaí-Açu spreads offshore in front of Santa Catarina Island, influenced by the 
presence of the plume from the southern rivers (Fig. 10, 1st and 2nd columns).

Another important conclusion is that river plumes from SBB can cross the region of Florianópolis and Cape Santa Marta and disperse through SB, forced by the summer southward wind. On the same way, the river plumes from both La Plata and SB rivers can reach regions inside SBB, north of Florianópolis, driven by winter northward wind, until the latitude $25.5^{\circ} \mathrm{S}$. Different wind regimes are found along the domain and with significant interannual variability, suggesting that it would be important to simulate longer periods in a future work. Some effort should be also made to obtain river discharges along the coast as faithfully as possible. In the region, river discharge may suffer great changes in El Niño years, for instance, and in such cases the usage of climatological or poorly measured river discharges may be unrealistic.

Acknowledgments Computations were performed at CESGA (Centro de Supercomputación de Galicia).

Funding M Marta-Almeida was funded by program Fellowsea (FP7PEOPLE-2012-COFUND, project id 600391). Model development has been partly funded by the European Union's Interreg Atlantic Area projects iFADO (EAPA_165/2016, http://www.ifado.eu) and MyCoast (EAPA_285/2016).

Open Access This article is licensed under a Creative Commons Attribution 4.0 International License, which permits use, sharing, adaptation, distribution and reproduction in any medium or format, as long as you give appropriate credit to the original author(s) and the source, provide a link to the Creative Commons licence, and indicate if changes were made. The images or other third party material in this article are included in the article's Creative Commons licence, unless indicated otherwise in a credit line to the material. If material is not included in the article's Creative Commons licence and your intended use is not permitted by statutory regulation or exceeds the permitted use, you will need to obtain permission directly from the copyright holder. To view a copy of this licence, visit http:// creativecommonshorg/licenses/by/4.0/.

\section{References}

Aguiar AL, Cirano M, Pereira J, Marta-Almeida M (2014) Upwelling processes along a western boundary current in the Abrolhos-Campos region of Brazil. Cont Shelf Res 85:42-59. https://doi.org/10.1016/j.csr.2014.04.013

Aguiar AL, Cirano M, Marta-Almeida M, Lessa GC, Valle-Levinson A (2018) Upwelling processes along the South Equatorial Current bifurcation region and the Salvador Canyon $\left(13^{\circ} \mathrm{S}\right)$, Brazil. Cont Shelf Res 171:77-96. https://doi.org/10.1016/j.csr.2018.10.001

Aguiar AL, Valle-Levinson A, Cirano M, Marta-Almeida M, Lessa GC, Paniagua-Arroyave J (2019) Ocean-estuary exchange variability in a large tropical estuary. Cont Shelf Res 172:33-49. https://doi.org/10.1016/j.csr.2018.11.001

Amorim FN, Cirano M, Marta-Almeida M, Middleton JF, Campos EJD (2013) The seasonal circulation of the Eastern Brazilian shelf between $10^{\circ} \mathrm{S}$ and $16^{\circ} \mathrm{S}$ : a modelling approach. Cont Shelf Res 65:121-140. https://doi.org/10.1016/j.csr.2013.06.008

Bettencourt JH, Rossi V, Hernández-García E, Marta-Almeida M, López C (2017) Characterization of the structure and crossshore transport properties of a coastal upwelling filament using three-dimensional finite-size lyapunov exponents. J Geophys Res 122:7433-7448. https://doi.org/10.1002/2017JC012700

Bordin LH, da C Machado E, Carvalho M, Freire AS, Fonseca AL (2019) Nutrient and carbon dynamics under the water mass seasonality on the continental shelf at the south Brazil bight. J Mar Syst 189:22-35. https://doi.org/10.1016/j.jmarsys.2018.09.006

Burrage D, Wesson J, Martinez C, Pérez T, Möller O, Piola A (2008) Patos Lagoon outflow within the Río de la Plata plume using an airborne salinity mapper: observing an embedded plume. Cont Shelf Res 28:1625-1638. https://doi.org/10.1016/j.csr.2007. 02.014

Cabanes C, Grouazel A, von Schuckmann K et al (2013) The CORA dataset: validation and diagnostics of in-situ ocean temperature and salinity measurements. Ocean Sci 9:1-18. https://doi.org/10. 5194/os-9-1-2013

Campos EJD, Goncalves JE, Ikeda Y (1995) Water mass characteristics and geostrophic circulation in the South Brazil Bight: Summer of 1991. J Geophys Res 100:18537. https://doi.org/10.1029/ $95 \mathrm{jc} 01724$

Campos EJD, Velhote D, da Silveira ICA (2000) Shelf break upwelling driven by Brazil Current Cyclonic Meanders. Geophys Res Lett 27:751-754. https://doi.org/10.1029/1999g1010502

Choi BJ, Wilkin JL (2007) The effect of wind on the dispersal of the Hudson river plume. J Phys Oceanogr 37:1878-1897. https://doi.org/10.1175/jpo3081.1

Dalbosco ALP (2019) Circulação na Plataforma Continental Interna de Santa Catarina. PhD thesis Universidade Federal de Santa Catarina, Florianápolis, Programa de Pós Graduação em Engenharia Ambiental

de Macedo-Soares LCP, Garcia CAE, Freire AS, Muelbert JH (2014) Large-scale ichthyoplankton and water mass distribution along the south Brazil shelf. PLoS One 9:e91241. https://doi.org/10.1371/journal.pone.0091241

de Souza MF, Schettini CAF (2014) Assessment of tide and wind effects on the hydrodynamics and interactions between Tijucas Bay and the adjacent continental shelf, Canta Catarina, Brazil. Rev Bras Geofís 32. https://doi.org/10.22564/rbgf.v32i3.506

de Souza RB, Robinson IS (2004) Lagrangian and satellite observations of the Brazilian Coastal Current. Cont Shelf Res 24:241-262. https://doi.org/10.1016/j.csr.2003.10.001

Egbert GD, Erofeeva SY (2002) Efficient inverse modeling of barotropic ocean tides. J Atmos Oceanic Technol 19:183-204. https://doi.org/10.1175/1520-0426(2002)019<0183:EIMOBO> 2.0.CO;2

Fong D, Geyer W (2002) The alongshore transport of freshwater in a surface-trapped river plume. J Phys Oceanogr 32:957-972. https://doi.org/10.1175/1520-0485(2002)032<0957:TATOFI> 2.0.CO; 2

Haidvogel DB, Arango H, Budgell WP et al (2008) Ocean forecasting in terrain-following coordinates: formulation and skill assessment of the Regional Ocean Modeling System. J Comput Phys 227:3595-3624. https://doi.org/10.1016/j.jcp.2007.06.016

Hetland RD (2005) Relating river plume structure to vertical mixing. J Phys Oceanogr 35:1667-1688. https://doi.org/10.1175/jpo2774.1

Hickey B, Geier S, Kachel N, MacFadyen A (2005) A bi-directional river plume: the Columbia outflow plume. J Geophys Res 23:801820

Hickey BM, Kudela RM, Nash JD et al (2010) River influences on shelf ecosystems: introduction and synthesis. J Geophys Res 115:C00B17. https://doi.org/10.1029/2009JC005452 
Horner-Devine AR, Hetland RD, MacDonald DG (2015) Mixing and transport in coastal river plumes. Annu Rev Fluid Mech 47:569594. https://doi.org/10.1146/annurev-fluid-010313-141408

Jerlov NG (1976) Marine optics. Elsevier, Amsterdam

Kao HY et al (2018) Aquarius salinity validation analysis. Aquarius Project Document AQ-014-PS-0016, NASA

Kourafalou VH, Androulidakis YS (2013) Influence of Mississippi River induced circulation on the Deepwater Horizon oil spill transport. J Geophys Res 118:3823-3842. https://doi.org/10.1002/jgrc. 20272

Lentz S (2004) The response of buoyant coastal plumes to upwelling-favorable winds. J Phys Oceanogr 34:2458-2469. https://doi.org/10.1175/JPO2647.1

Lohrenz SE, Fahnenstiel GL, Redalje DG, Lang GA, Dagg MJ, Whitledge TE, Dortch Q (1999) Nutrients, irradiance, and mixing as factors regulating primary production in coastal waters impacted by the Mississippi River plume. Cont Shelf Res 19:1113-1141. https://doi.org/10.1016/S0278-4343(99)00012-6

Magris RA, Marta-Almeida M, Monteiro JA, Ban NC (2019) A modelling approach to assess the impact of land mining on marine biodiversity: assessment in coastal catchments experiencing catastrophic events (SW Brazil). Sci Total Environ 659:828-840. https://doi.org/10.1016/j.scitotenv.2018.12.238

Marchesiello P, McWilliams JC, Shchepetkin A (2001) Open boundary conditions for long-term integration of regional oceanic models. Ocean Model 3:1-20. https://doi.org/10.1016/S14635003(00)00013-5

Marta-Almeida M, Pereira J, Cirano M (2011a) Development of a pilot Brazilian regional operational ocean forecast system, REMO-OOF. J Oper Oceanogr 4:3-15. https://doi.org/10.1080/ 1755876X.2011.11020123

Marta-Almeida M, Ruiz-Villarreal M et al (2011b) OOF $\varepsilon$ : a Python engine for automating regional and coastal ocean forecasts. Environ Model Softw 26:680-682. https://doi.org/10.1016/j.envsoft. 2010.11.015

Marta-Almeida M, Hetland RD, Zhang X (2013a) Evaluation of model nesting performance on the Texas-Louisiana continental shelf. $\mathrm{J}$ Geophys Res 118:2476-2491. https://doi.org/10.1002/jgrc.20163

Marta-Almeida M, Ruiz-Villarreal M, Pereira J, Otero P, Cirano M, Zhang X, Hetland RD (2013b) Efficient tools for marine operational forecast and oil spill tracking, 71:139-151. https://doi.org/10.1016/j.marpolbul.2013.03.022

Marta-Almeida M, Mendes R, Amorim FN, Cirano M, Dias JM (2016) Fundão Dam collapse: oceanic dispersion of River Doce after the greatest Brazilian environmental accident 112:359-364, https://doi.org/10.1016/j.marpolbul.2016.07.039

Marta-Almeida M, Cirano M, Soares CG, Lessa GC (2017) A numerical tidal stream energy assessment study for Baía de Todos os Santos, Brazil. Renew Energ 107:271-287. https://doi.org/10.1016/j. renene.2017.01.047

Marta-Almeida M, Lessa GC, Aguiar AL, Amorim FN, Cirano M (2019) Realistic modelling of shelf-estuary regions: a multicorner configuration for Baía de Todos os Santos. Ocean Dynam 69:1311-1331. https://doi.org/10.1007/s10236-019-01304-z

Matano RP, Palma ED, Piola AR (2010) The influence of the Brazil and Malvinas Currents on the Southwestern Atlantic Shelf circulation. Ocean Sci 6:983-995. https://doi.org/10.5194/os-6-983-2010

Mendonça LF, Souza RB, Aseff CRC, Pezzi LP, Möller OO, Alves RCM (2017) Regional modeling of the water masses and circulation annual variability at the Southern Brazilian Continental Shelf. J Geophys Res 122:1232-1253. https://doi.org/10.1002/ 2016jc011780

Möller OO, Piola AR, Freitas AC, Campos EJ (2008) The effects of river discharge and seasonal winds on the shelf off southeastern South America. Cont Shelf Res 28:1607-1624. https://doi.org/10.1016/j.csr.2008.03.012
Noernberg MA, Alberti AL (2014) Oceanography variability in the inner shelf of Paraná, Brazil: Spring condition. Rev Bras Geofís 32:197-206. https://doi.org/10.22564/rbgf.v32i2.451

Oliveira LR, Piola AR, Mata MM, Soares ID (2009) Brazil Current surface circulation and energetics observed from drifting buoys. J Geophys Res 114:C10006. https://doi.org/10.1029/ 2008jc004900

Olson DB, Podestá GP, Evans RH, Brown OB (1988) Temporal variations in the separation of Brazil and Malvinas Currents. Deep Sea Res Part A 35:1971-1990. https://doi.org/10.1016/01980149(88)90120-3

Osadchiev A, Korshenko E (2017) Small river plumes off the northeastern coast of the Black Sea under average climatic and flooding discharge conditions. Ocean Sci 13:465-482. https://doi.org/10.5194/os-13-465-2017

Otero P, Ruiz-Villarreal M, Peliz A (2008) Variability of river plumes off Northwest Iberia in response to wind events. J Mar Syst 72:238-255. https://doi.org/10.1016/j.jmarsys.2007.05.016

Palma ED (2004) A comparison of the circulation patterns over the Southwestern Atlantic Shelf driven by different wind stress climatologies. Geophys Res Lett 31:L24303. https://doi.org/10.1029/ $2004 \mathrm{gl} 021068$

Palma ED, Matano RP, Piola AR (2004) A numerical study of the Southwestern Atlantic Shelf circulation: barotropic response to tidal and wind forcing. J Geophys Res 109:C08014. https://doi.org/10.1029/2004jc002315

Palma ED, Matano RP, Piola AR (2008) A numerical study of the Southwestern Atlantic Shelf circulation: stratified ocean response to local and offshore forcing. J Geophys Res 113:C11010. https://doi.org/10.1029/2007jc004720

Peliz Á, Rosa TL, Santos AP, Pissarra JL (2002) Fronts, jets, and counter-flows in the Western Iberian upwelling system. J Mar Syst 35:61-77. https://doi.org/10.1016/s0924-7963(02)00076-3

Pezzi LP, Souza RB, Farias PC, Acevedo O, Miller AJ (2016) Air-sea interaction at the Southern Brazilian Continental Shelf: in situ observations. J Geophys Res 121:6671-6695. https://doi.org/10.1002/2016jc011774

Piola AR (2005) The influence of the Plata River discharge on the western South Atlantic shelf. Geophys Res Lett 32:L01603. https://doi.org/10.1029/2004gl021638

Piola AR, Matano RP (2001) Brazil and Falklands (Malvinas) currents. In: Steele JH (ed) Encyclopedia of ocean sciences. Academic Press, Oxford, pp 340-349. https://doi.org/10.1006/rwos.2001. 0358

Piola AR, Campos EJD, Möller OO, Charo M, Martinez C (2000) Subtropical Shelf Front off eastern South America. J Geophys Res 105:6565-6578. https://doi.org/10.1029/1999jc000300

Piola AR, Möller OO, Guerrero RA, Campos EJ (2008) Variability of the subtropical shelf front off eastern South America: Winter 2003 and Summer 2004. Cont Shelf Res 28:1639-1648. https://doi.org/10.1016/j.csr.2008.03.013

Pujol MI, Faugère Y, Taburet G, Dupuy S, Pelloquin C, Ablain M, Picot N (2016) DUACS DT2014: the new multi-mission altimeter data set reprocessed over 20 years. Ocean Sci 12:1067-1090. https://doi.org/10.5194/os-12-1067-2016

Rayson MD, Gross ES, Hetland RD, Fringer OB (2016) Time scales in Galveston Bay: an unsteady estuary. J Geophys Res 121:22682285. https://doi.org/10.1002/2015JC011181

Saha S, Moorth S, Pan HL et al (2010) The NCEP Climate Forecast System Reanalysis. Bull Am Meteor Soc 91:1015-1057. https://doi.org/10.1175/2010BAMS3001.1

Saldías GS, Largier JL, Mendes R, Pérez-Santos I, Vargas CA, Sobarzo M (2016) Satellite-measured interannual variability of turbid river plumes off central-southern Chile: spatial patterns and the influence of climate variability. Prog Oceanogr 146:212-222. https://doi.org/10.1016/j.pocean.2016.07.007 
Satyamurty P, Nobre CA, Dias PLS (1998) South America. In: Karoly DJ, Vincent DG (eds) Meteorology of the southern Hemisphere. American Meteorological Society, pp 119-139. https://doi.org/10.1007/978-1-935704-10-2_5

Soares I, Möller O Jr (2001) Low-frequency currents and water mass spatial distribution on the southern Brazilian shelf. Cont Shelf Res 21:1785-1814. https://doi.org/10.1016/S0278-4343(01)00024-3

Soares ID, Kourafalou V, Lee TN (2007a) Circulation on the western South Atlantic continental shelf: 1. Numerical process studies on buoyancy. J Geophys Res 112:C04002. https://doi.org/10.1029/ 2006JC003618

Soares ID, Kourafalou V, Lee TN (2007b) Circulation on the western South Atlantic continental shelf: 2. Spring and autumn realistic simulations. J Geophys Res 112:C04003. https://doi.org/10.1029/ 2006JC003620

Stramma L, Ikeda Y, Peterson RG (1990) Geostrophic transport in the Brazil current region north of $20^{\circ} \mathrm{S}$. Deep Sea Res Part A 37:1875-1886. https://doi.org/10.1016/0198-0149(90)90083-8

Wallcraft AJ, Metzger EJ, Carroll SN (2009) Design description for the HYbrid Coordinate Ocean Model (HYCOM) version 2.2. Tech. rep. Naval Research Laboratory, Stennins Space Center
Warrick JA, Farnsworth KL (2017) Coastal river plumes: collisions and coalescence. Prog Oceanogr 151:245-260. https://doi.org/10. 1016/j.pocean.2016.11.008

Waterhouse J, Brodie J, Lewis S, Mitchell A (2012) Quantifying the sources of pollutants in the Great Barrier Reef catchments and the relative risk to reef ecosystems 65: 394-406, https://doi.org/10.1016/j.marpolbul.2011.09.031

Whitney MM, Garvine RW (2005) Wind influence on a coastal buoyant outflow. J Geophys Res 110:C03014. https://doi.org/10.1029/ 2003JC002261

Yankovsky AE, Chapman DC (1997) A simple theory for the fate of buoyant coastal discharges. J Phys Oceanogr 27:1386-1401. https: //doi.org/10.1175/1520-0485(1997)027<1386:ASTFTF>2.0.CO;2

Zavialov P, Möller O, Campos E (2002) First direct measurements of currents on the continental shelf of Southern Brazil. Cont Shelf Res 22:1975-1986. https://doi.org/10.1016/s0278-4343(02)00049-3

Zhang X, Hetland RD, Marta-Almeida M, DiMarco SF (2012) A numerical investigation of the Mississippi and Atchafalaya freshwater transport, filling and flushing times on the Texas-Louisiana Shelf. J Geophys Res 117:C11009. https://doi.org/10.1029/ 2012JC008108

\section{Affiliations}

\section{Martinho Marta-Almeida $^{1,2}$ (D) . Anna Dalbosco ${ }^{3}$. David Franco ${ }^{3}$ - Manuel Ruiz-Villarreal ${ }^{2}$}

1 Universidade de Vigo, Campus Universitario Lagoas-Marcosende, Vigo, Spain

2 Centro Oceanográfico de A Coruña, Instituto Español de Oceanografía (IEO), A Coruña, Spain

3 Universidade Federal de Santa Catarina, Florianópolis, SC, Brazil 